\title{
Barium uptake into the shells of the common mussel (Mytilus edulis) and the potential for estuarine paleo-chemistry reconstruction
}

David P. Gillikin ${ }^{1, *}$, Frank Dehairs ${ }^{1}$, Anne Lorrain ${ }^{2,3}$, Dirk Steenmans ${ }^{1}$, Willy

5 Baeyens ${ }^{1}$, and Luc André ${ }^{2}$

$10{ }^{1}$ Department of Analytical and Environmental Chemistry, Vrije Universiteit Brussel, Pleinlaan 2, B-1050 Brussels, Belgium. Tel.: +32-2-629-1265; fax: +32-2-629-3274;

E-mail addresses: david.gillikin@vub.ac.be, david@scientificproofreading.com;

* Corresponding author.

$15{ }^{2}$ Section of Mineralogy and Petrography, Royal Museum for Central Africa, Leuvensesteenweg 13, B-3080 Tervuren, Belgium.

${ }^{3}$ Current address: UR Thetis, IRD-CRH (Centre de Recherche Halieutique Méditerranéenne et Tropicale), Avenue Jean Monnet - BP 171, 34203 Sète Cedex, 20 France.

25

Submitted to Geochimica et Cosmochimica Acta on 03 February 2005

Revised and re-submitted on 12 July 2005

Revised and re-submitted on 14 September 2005 


\begin{abstract}
In this study we test if calcite shells of the common mussel, Mytilus edulis, contain barium in proportion to the water in which they grew. Similar to all bivalves analyzed to date, the $[\mathrm{Ba} / \mathrm{Ca}]_{\text {shell }}$ profiles are characterized by a relatively flat background

$45[\mathrm{Ba} / \mathrm{Ca}]_{\text {shell }}$, interrupted by sharp $[\mathrm{Ba} / \mathrm{Ca}]_{\text {shell }}$ peaks. Previous studies have focused on these $[\mathrm{Ba} / \mathrm{Ca}]_{\text {shell }}$ peaks, but not on the background $[\mathrm{Ba} / \mathrm{Ca}]_{\text {shell }}$. We show that in both laboratory and field experiments, there is a direct relationship between the background $[\mathrm{Ba} / \mathrm{Ca}]_{\text {shell }}$ and $[\mathrm{Ba} / \mathrm{Ca}]_{\text {water }}$ in $M$. edulis shells. The laboratory and field data provided background $\mathrm{Ba} / \mathrm{Ca}$ partition coefficients $\left(\mathrm{D}_{\mathrm{Ba}}\right)$ of $0.10 \pm 0.02$ and 0.071

$50 \pm 0.001$, respectively. This range is slightly higher than the $\mathrm{D}_{\mathrm{Ba}}$ previously determined for inorganic calcite, and slightly lower than foraminiferal calcite. These data suggest that $M$. edulis shells can be used as an indicator of $[\mathrm{Ba} / \mathrm{Ca}]_{\text {water, }}$, and therefore, fossil or archaeological M. edulis shells could be used to extend knowledge of estuarine dissolved Ba throughputs back in time. Moreover, considering the inverse relationship 55 between $[\mathrm{Ba} / \mathrm{Ca}]_{\text {water }}$ and salinity, background $[\mathrm{Ba} / \mathrm{Ca}]_{\text {shell }}$ data could be used as an estuary specific indicator of salinity. The cause of the $[\mathrm{Ba} / \mathrm{Ca}]_{\text {shell }}$ peaks are more confusing, both the laboratory and field experiments indicate that they cannot be used as a direct proxy of $[\mathrm{Ba} / \mathrm{Ca}]_{\text {water }}$ or phytoplankton production, but may possibly be caused by barite ingestion.
\end{abstract}

60

Keywords: $\mathrm{Ba} / \mathrm{Ca}$, biogenic carbonate, mollusk, estuary, isotope, diet, hemolymph, trace element, salinity 


\section{INTRODUCTION}

In recent years there has been an increasing amount of papers presenting high resolution elemental profiles in bivalve shells. Unlike corals and foraminifera, much of the bivalve data presented suggests that many of these elemental profiles (e.g., Sr, $\mathrm{Mn}, \mathrm{Pb}, \mathrm{U})$, which often largely differ from expected concentrations based on inorganic and other biogenic carbonates, cannot be used as proxies of environmental conditions (e.g., Stecher et al., 1996; Purton et al., 1999; Vander Putten et al, 2000; Takesue and van Geen, 2004; Freitas et al., 2005; Gillikin et al., 2005a; Gillikin, 2005). There have been some promising reports of bivalve shell $\mathrm{Mg} / \mathrm{Ca}$ ratios as a proxy of sea surface temperature (SST) (Klein et al., 1996), but other reports illustrate that this is not always the case, and is apparently strongly species specific (Vander

5 Putten et al, 2000; Takesue and van Geen, 2004; Freitas et al., 2005; Gillikin, 2005; Lorrain et al., in press). Bivalve shell $\mathrm{Ba} / \mathrm{Ca}$ ratios on the other hand have been shown to be highly reproducible between specimens and have been hypothesized to be a proxy of both particulate Ba (Stecher et al., 1996; Vander Putten et al, 2000; Lazareth et al., 2003) and dissolved Ba (Torres et al., 2001), and therefore could be particularly promising.

The oceanic barium cycle has received much attention over the past several decades (e.g., Chan et al., 1977; Dehairs et al., 1980; 1992; Paytan and Kastner, 1996; McManus et al., 2002; Jacquet et al., 2005). This is due in part to the use of Ba as a paleoproductivity and paleoalkalinity proxy (Dymond et al., 1992; Lea, 1993; McManus et al., 1999). Barium enters the oceans from river or ground water inputs, which pass through estuaries and the coastal zone (Carroll et al., 1993; Guay and Falkner, 1997; 1998; Shaw et al., 1998). Obtaining insight into the magnitude and temporal variability of these $\mathrm{Ba}$ inputs is important for understanding the oceanic $\mathrm{Ba}$ cycle and residence time, as shown by many studies (Edmond et al., 1978; Moore and Edmond, 1984; Coffey et al., 1997; Guay and Falkner, 1997; 1998); however, historical records of riverine inputs are lacking. Having a proxy of Ba inputs from estuaries or the coastal zone that can be extended back in time would be highly valuable. 
Barium / calcium ratios have been proposed as a proxy of dissolved seawater $\mathrm{Ba} / \mathrm{Ca}$ in aragonitic corals (Tudhope et al., 1996; McCulloch et al., 2003; Sinclair and McCulloch, 2004), calcitic foraminifera (Lea and Boyle, 1989; 1991) and vesicomyid clam shells (Torres et al., 2001), providing information on salinity, nutrient and alkalinity distributions in past oceans.

To date, all published records of high resolution Ba profiles in bivalve shells (both aragonite and calcite) have similar characteristics with a more or less stable background $\mathrm{Ba}$ concentration, interspaced with sharp episodic Ba peaks (Stecher et 105 al., 1996; Toland et al., 2000; Vander Putten et al., 2000; Torres et al., 2001; Lazareth et al., 2003; Gillikin, 2005). Stecher et al. (1996) first proposed that these peaks were the result of the filter feeding bivalves ingesting Ba-rich particles associated with diatom blooms, as either phytoplankton, or barite. It is well known that primary productivity and barite formation are closely associated (e.g., Dehairs et al., 1980;

110 1987). Once inside the digestive tract, Ba may be metabolized and moved via the hemolymph to the extrapallial fluid (EPF), where shell precipitation occurs (Wilbur and Saleuddin, 1983). Vander Putten et al. (2000) found a remarkable coincidence of the $\mathrm{Ba}$ peaks in several mussel shells collected at the same site, providing further evidence that an environmental parameter controls their occurrence. However, this 115 hypothesis remains untested. Furthermore, there are no studies reporting the $\mathrm{Ba} / \mathrm{Ca}$ partition coefficient $\left(\mathrm{D}_{\mathrm{Ba}}=(\mathrm{Ba} / \mathrm{Ca})_{\text {carbonate }} /(\mathrm{Ba} / \mathrm{Ca})_{\text {water }}\right)$ for bivalves and the only study suggesting that bivalves record dissolved Ba may possibly have included the effects of these shell Ba peaks (see Torres et al., 2001). Rosenthal and Katz (1989) found a good correlation between dissolved $\mathrm{Ba} / \mathrm{Ca}$ and shell $\mathrm{Ba} / \mathrm{Ca}$ in two species of

120 freshwater aragonitic gastropods, but analyzed large shell sections and may have also included shell $\mathrm{Ba} / \mathrm{Ca}$ peaks.

The aim of this study was to assess if calcite shells of the common mussel, Mytilus edulis, contain barium in proportion to the water in which they grew. To validate this 125 proxy, we measured Ba concentrations in the shells, soft tissues and hemolymph of mussels exposed to different levels of dissolved $\mathrm{Ba}$ in the laboratory as well as mussels fed diets with varying $\mathrm{Ba}$ concentrations. To calibrate the proxy on natural populations, a field study along the Westerschelde Estuary (The Netherlands) was conducted, where mussels were grown along a salinity gradient while elemental 
130 concentrations and physico-chemical water parameters were regularly monitored. This experimental setup allowed us to compare data from both culture and natural situations.

\section{MATERIALS AND METHODS}

\section{$135 \quad 2.1$ Laboratory experiments}

\subsubsection{Dissolved Ba experiment}

Mytilus edulis were collected from the Oosterschelde estuary near Wemeldinge, The

140 Netherlands (salinity $\sim 35$; temperature $\sim 8{ }^{\circ} \mathrm{C}$ ) on 1 March 2004 (Fig. 1). Epibionts were gently removed and the mussels were acclimated to laboratory conditions at 9.2 $\pm 0.3{ }^{\circ} \mathrm{C}$ (mean \pm standard deviation) for 7 days, then another 14 days at $14.7 \pm 0.2{ }^{\circ} \mathrm{C}$ (i.e., 21 days acclimation; temperature monitored hourly with a TidBit data logger, Onset Computer Corp.). During acclimation, mussels were fed three times per week

145 with $12 \mathrm{mg}$ of dried yeast per animal per week (Artemic Systems, LANSY PZ). After the acclimation period, 40 mussels $(2.8 \pm 0.3 \mathrm{~cm}$ length $)$ were selected for the 'dissolved $\mathrm{Ba}$ ' experiment and were stained with calcein $\left(200 \mathrm{mg} \mathrm{l}^{-1} ; \mathrm{C}_{30} \mathrm{H}_{26} \mathrm{~N}_{2} \mathrm{O}_{13}\right.$; Sigmal Chemical) for 20 hours to mark the beginning of the experiment in the shell (see Rowley and Mackinnon, 1995). Afterwards, 10 mussels were placed in each of four aquaria containing 101 of filtered $(10 \mu \mathrm{m})$ North Sea water spiked with approximately $0,110,220$ and $440 \mathrm{nmol} \mathrm{l}^{-1}$ of $\mathrm{Ba}\left(\mathrm{as} \mathrm{BaCl}_{2}\right)$ (Table 1). Water was continuously circulated through acid washed plastic filters (except during feeding periods, see further) and was aerated. Mussels were fed the same quantities of yeast as during the acclimation period. Feeding took place for three hours, three times per

155 week. Mussels were fed in their separate aquaria during which the filtration pumps were turned off. This experiment ran for 36 days, during which the water in all tanks was changed weekly (similar to Lorens and Bender, 1980) and was maintained at 16.4 $\pm 0.6{ }^{\circ} \mathrm{C}$ with a $\mathrm{pH}$ of $7.9 \pm 0.1$ and salinity of $36.4 \pm 0.9$ (on occasion salinity was adjusted with deionized water $\left(>18 \mathrm{M} \Omega \mathrm{cm}^{-1}\right)$ to compensate for evaporation; $\mathrm{pH}$ and salinity were measured with a WTW multiline P4 multimeter). Water samples were taken two times per week for $[\mathrm{Ba} / \mathrm{Ca}]_{\text {water }}$ using syringe filters (Macherey-Nagel; Chromafil A45/25; cellulose mixed esters; $0.45 \mu \mathrm{m}$ pore size), once just before and 
after a water change, and were acidified with trace metal grade $\mathrm{HCl}$ to $\sim \mathrm{pH} 3$.

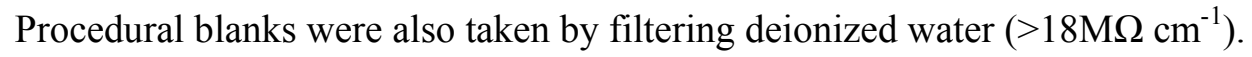

\subsubsection{Feeding experiment}

To assess the effect of $\mathrm{Ba}$ being ingested as food, a feeding experiment was conducted. In a fifth aquarium, two plastic mesh baskets, each with 10 mussels were held under the same conditions, except that there was 201 of water to compensate for the higher density of animals and they were fed differently. These mussels were fed in separate aquaria with different foods. One batch was fed a slurry of living phytoplankton (Chlamidomonas reinhardii) grown in a 'normal' Tris-Acetate-

175 Phosphate (TAP) medium (hereafter referred to as phyto +0 ) with the phytoplankton containing $5.87 \pm 0.51 \mathrm{nmol} \mathrm{g}^{-1}$ dry weight (DW) Ba $(\mathrm{n}=3)$, whereas the other batch were fed the same phytoplankton species, which were grown in a Ba rich TAP medium (spiked with $730 \mathrm{nmol}^{-1} \mathrm{Ba}$; hereafter referred to as phyto +100 ; see Steenmans (2004) for more details regarding phytoplankton culturing) with $[\mathrm{Ba}]=$

$18014.56 \pm 0.95 \mathrm{nmol} \mathrm{g}^{-1} \mathrm{DW}(\mathrm{n}=3)$. Both batches were fed for 1 hour per day, five days per week, with a total of $18 \mathrm{mg}$ phytoplankton (DW) per animal per week. This provided three levels of $\mathrm{Ba}$ in food given to mussels maintained in normal seawater Ba concentrations (i.e., yeast (with $[\mathrm{Ba}]=3.35 \pm 0.32 \mathrm{nmol} \mathrm{g}^{-1} \mathrm{DW}(\mathrm{n}=3)$ ), phyto +0 and phyto +100). After feeding, mussels were returned to their aquarium. This

185 experiment was run for 29 days; water maintenance and sampling was similar to the dissolved Ba experiment. Mussels were sampled (7 per treatment) approximately 24 hours after the last feeding period. Mytilus edulis hemolymph has been determined to have a slow turnover time based on the residence time ( $>3$ days) of a fluorescent dye (Gillikin, 2005). Therefore, this sampling design should have captured any $\mathrm{Ba}$ entering the hemolymph from the food.

\subsubsection{Hemolymph, soft tissue and shell sampling}

After the experiments were complete, mussels were removed from their aquaria one at 195 a time and were sampled for hemolymph, soft tissues and shells. Hemolymph was sampled by blotting the shell dry, and then gently prying open the valves with a 
scalpel, draining the mantle cavity and then sampling the hemolymph from the adductor muscle with a sterile $5 \mathrm{ml}$ syringe and needle. Procedural blanks were prepared by drawing deionized water into a new syringe. Whole tissues were dissected from the valves using a scalpel. Samples (hemolymph and tissues) and blanks were transferred to micro-centrifuge tubes and were immediately frozen to -20 ${ }^{\circ} \mathrm{C}$ until analysis. Shells were rinsed with deionized water $\left(>18 \mathrm{M} \Omega \mathrm{cm}^{-1}\right)$ and were air dried.

205 A condition index was used to compare mussel health at the end of the experiments ([shell length / shell width] / tissue dry weight) to mussels health at the end of the acclimation period (beginning of experiments), which indicated that all animals were healthy (ANOVA, LSD test, $\mathrm{p}>0.05$ for all).

\subsection{Field experiment}

Mytilus edulis ( $3 \mathrm{~cm}$ ) were collected from the Oosterschelde (The Netherlands; Fig. 1). The Oosterschelde estuary was dammed in the late eighties and now has more or less marine salinities ( $\mathrm{S}>30$; Gerringa et al., 1998). Mussels were transported back to

215 the laboratory where epibionts were removed. They were then stained with calcein as in the previously described experiments. Within the next week (on 24 Oct. 2001), 50 mussels were placed into four stainless steel cages and these were deployed along an estuarine salinity gradient in the Westerschelde estuary (Fig. 1; see Baeyens et al., 1998 for a general description of the Westerschelde). Cages were attached at the same tidal level as the highest density of 'local' mussels at Ossenisse (OS; the most upstream occurrence of wild Mytilus populations), Griete (GR), Hooftplaat (HF), and Knokke (KN; Fig. 1). Water temperature was monitored at each site hourly using a TidBit data logger. Near-shore water was sampled monthly at high tide for one year (Nov. 2001- Nov. 2002) and every two weeks between March and May for salinity, dissolved $\mathrm{Ba} / \mathrm{Ca}$, and chlorophyll a (Chl a). Salinity was measured in situ with a WTW multiline P4 multimeter. $[\mathrm{Ba} / \mathrm{Ca}]_{\text {water }}$ was sampled by filtering 250 to $500 \mathrm{ml}$ of seawater through $0.4 \mu \mathrm{m}$ polycarbonate filters (Osmonics poretics). The filtrate was acidified with trace metal grade $\mathrm{HNO}_{3}$ to $\sim \mathrm{pH}$ 3. Blanks were prepared by filtering deionized water $\left(>18 \mathrm{M} \Omega \mathrm{cm}^{-1}\right)$ through the same system and blank filter.

230 Phytoplankton pigments were sampled by filtering 200 to $500 \mathrm{ml}$ of seawater through 
Whatman GF-F filters (nominal porosity $=0.7 \mu \mathrm{m}$ ). Filters were wrapped in aluminum foil and placed in liquid nitrogen; three replicates were taken at each sampling. Upon return to the laboratory, samples were transferred to a $-85^{\circ} \mathrm{C}$ freezer until analysis.

235 Mussels were collected on four different dates (29 Sept. 02, 9 Dec. 02, 20 Feb. 03 and 21 Apr. 03). Mussels transplanted to OS did not survive (undoubtedly due to the salinity shock) and therefore local mussels from this site were used. Similarly, the wave action at $\mathrm{KN}$ repeatedly destroyed cages and all mussels were lost; so again at this site, mussels from the local population were used.

\subsection{Sample preparation and analysis}

All water samples for dissolved $\mathrm{Ba}$ and $\mathrm{Ca}$ analysis were diluted with deionized water $\left(>18 \mathrm{M} \Omega \mathrm{cm}^{-1}\right)$ to assure a salt concentration less than $0.2 \%$. Ba was measured on a 245 VG PlasmaQuad II+ inductively coupled plasma mass spectrometer (ICP-MS) using In as an internal standard. Calcium was measured with an IRIS Thermo Jarrell Ash Corp. ICP- optical emission spectrometer (ICP-OES) using Yt and $\mathrm{Au}$ as internal standards. Certified reference materials (CRM) were run to check for precision and accuracy. The reproducibility of the SLRS-3 water standard was $<4 \%$ (\%RSD) for

250 both $\mathrm{Ba}$ and $\mathrm{Ca}$ and mean values were within $5 \%$ of the recommended values for both elements $(n=8)$. Phytoplankton pigments were analyzed at NIOO-CEME, Yerseke, NL, using reverse-phase HPLC (see Gieskes et al., 1988) with a reproducibility of $2.7 \%$ (or $0.3 \mu \mathrm{g} / 1 ; 1 \sigma)$ for $\mathrm{Chl}$ a, based on an in-house standard ( $\mathrm{n}=$ 7).

Hemolymph samples were defrosted and $150 \mu \mathrm{l}$ of sample was pipetted into a clean Teflon beaker. The sample was digested by adding $150 \mu 1 \mathrm{HNO}_{3}$ and $150 \mu \mathrm{H}_{2} \mathrm{O}_{2}$ (trace metal grade) and allowing the reaction to take place in the sealed beaker at 60 ${ }^{\circ} \mathrm{C}$ for more than 12 hours. In and Re were used as internal standards to control 260 instrument fluctuations. Samples were analyzed for $\mathrm{Ba}$ and $\mathrm{Ca}$ on a Finnigan Element2 High Resolution-Inductively Coupled Plasma-Mass Spectrometer (HR-ICPMS). Samples were diluted 20 times with deionized water $\left(>18 \mathrm{M} \Omega \mathrm{cm}^{-1}\right)$ to assure a salt concentration less than $0.2 \%$. Reproducibility of seawater and hemolymph 
samples was $<5 \%$ for both $\mathrm{Ba}$ and $\mathrm{Ca}\left([\mathrm{Ba} / \mathrm{Ca}]_{\text {hemolymph }}=3.8 \pm 0.2 \mu \mathrm{mol} / \mathrm{mol}, \mathrm{n}=9\right.$, 265 and $\left.[\mathrm{Ba} / \mathrm{Ca}]_{\mathrm{water}}=65.1 \pm 2.1 \mu \mathrm{mol} / \mathrm{mol}, \mathrm{n}=9\right)$.

Three animals from each laboratory treatment were randomly selected and their tissues were digested following the protocol of Blust et al. (1988). Briefly, samples were digested in $2 \mathrm{ml}$ of bi-distilled $\mathrm{HNO}_{3}$ for at least 12 hours and were then microwave digested with the addition of $1 \mathrm{ml}$ of Ultrapure $\mathrm{H}_{2} \mathrm{O}_{2}$. The digested tissue samples were then analyzed for $\mathrm{Ba}$ and $\mathrm{Ca}$ with the HR-ICP-MS in the same manner as hemolymph (see above). Reproducibility was established by running different CRMs, the DORM-2 Dogfish muscle (National Research Council of Canada) and the NIST 1566a oyster tissue. For DORM-2, reproducibility was $4.8 \%([\mathrm{Ba} / \mathrm{Ca}]=1.16 \pm$ $2750.05 \mathrm{mmol} / \mathrm{mol}, \mathrm{n}=5)$, while it was $7.6 \%$ for 1566 a oyster tissue $([\mathrm{Ba} / \mathrm{Ca}]=0.22 \pm$ $0.02 \mathrm{mmol} / \mathrm{mol}, \mathrm{n}=7$ ). Neither of these CRMs are certified for Ba concentrations, but values obtained for NIST 1566a were within $10 \%$ of previously published values (see Buckel et al., 2004).

280 Shells were sectioned along the axis of maximal growth using a wet diamond saw. Thick sections were viewed under an optical microscope with UV light and calcein marks were mapped for each shell. Only shells from the laboratory experiments with greater than $70 \mu \mathrm{m}$ of new growth were used (the laser ablation spot is $50 \mu \mathrm{m}$ in diameter, see further). Unfortunately, mussels from the feeding experiment were not 285 exposed to calcein for a long enough period (4 hours). Therefore, the new growth could not be assessed and these shells could not be analyzed for $\mathrm{Ba} / \mathrm{Ca}$ ratios. Shells from the field experiment were first sampled for stable isotopes. Carbonate powder was milled from the shell cross-sections using a $300 \mu \mathrm{m}$ drill bit and a Merchantek Micromill (a fixed drill and computer controlled micro positioning device), which 290 allows precise sampling. Samples were milled from the outer calcite shell layer. Various sampling distances were used $(150 \mu \mathrm{m}$ to $1 \mathrm{~mm})$ depending on growth rate (i.e., fewer samples in regions of high growth). Oxygen and carbon isotope analyses were performed using a ThermoFinnigan Kiel III coupled to a ThermoFinnigan Delta + XL dual inlet isotope ratio mass spectrometer (IRMS). The samples were 295 calibrated against the NBS-19 standard $\left(\delta^{18} \mathrm{O}=-2.20 \%, \delta^{13} \mathrm{C}=+1.95 \%\right.$ ) and data are reported as \%o VPDB using the conventional delta notation. The reproducibility 
$(1 \sigma)$ of the routinely analyzed carbonate standard is better than $0.1 \%$ for both $\delta^{18} \mathrm{O}$ and $\delta^{13} \mathrm{C}$ (more details can be found in Gillikin et al., 2005b). High resolution $\mathrm{Ba} / \mathrm{Ca}$ profiles from field grown shells were obtained using either solution nebulization HRICP-MS (SN-HR-ICP-MS) on micromilled powders (powders were milled directly beneath the isotope sample to assure proper alignment of the data and to remove surface contamination) or by laser ablation ICP-MS (LA-ICP-MS; see below). All shells from the dissolved $\mathrm{Ba}$ experiment with adequate growth were analyzed for $\mathrm{Ba} / \mathrm{Ca}$ using the LA-ICP-MS.

Carbonate powders for $\mathrm{Ba} / \mathrm{Ca}$ analyses $(\sim 150 \mu \mathrm{g})$ were dissolved in a $1 \mathrm{ml} 5 \%$ $\mathrm{HNO}_{3}$ solution containing $1 \mathrm{ppb}$ of In and Re, which were used as internal standards. Reproducibility of $\mathrm{Ba} / \mathrm{Ca}$ ratios over the sampling period was $6.6 \%$ (1б; or 0.06 $\mu \mathrm{mol} / \mathrm{mol}$ ) based on replicate measurements of a $M$. edulis in-house reference 310 material $([\mathrm{Ba} / \mathrm{Ca}]=0.96 \mu \mathrm{mol} / \mathrm{mol} ; \mathrm{n}=8)$. Accuracy was assessed using the USGS MACS1 carbonate standard $([\mathrm{Ba} / \mathrm{Ca}]=84.76 \mu \mathrm{mol} / \mathrm{mol})$ and was found to be within 1 $\%$ of the recommended value $(n=6$; values from S. Wilson, USGS, unpublished data, 2004).

315 Data from LA-ICP-MS were calibrated using both the NIST 610 (values from Pearce et al. (1997)) and the USGS MACS1 (values from S. Wilson, USGS, unpublished data, 2004). The laser was shot ( $\sim 50 \mu \mathrm{m}$ spots $)$ directly in the holes of the isotope sampling allowing direct alignment of $\mathrm{Ba} / \mathrm{Ca}$ and isotope profiles for the field experiment (cf. Toland et al., 2000). All shells from the laboratory experiment were analyzed in front of the calcein mark (one analysis per shell, if growth was less than $50 \mu \mathrm{m}$, the shell was not sampled). Calibration (including gas blank subtraction, ${ }^{43} \mathrm{Ca}$ normalization, and drift correction) was performed offline following Toland et al. (2000). $\mathrm{Ba} / \mathrm{Ca}$ reproducibility over the sampling period was $0.11 \mu \mathrm{mol} / \mathrm{mol}(1 \sigma$; or $12.8 \%$ ) at the $1 \mu \mathrm{g} / \mathrm{g}$ level $(\mathrm{MACS} 2$, mean $=0.9 \mu \mathrm{mol} / \mathrm{mol}, \mathrm{n}=17)$ and $5.9 \mu \mathrm{mol} / \mathrm{mol}$ $325(1 \sigma$; or $7.3 \%)$ at the $80 \mu \mathrm{g} / \mathrm{g}$ level $(\mathrm{MACS} 1$, mean $=80.5 \mu \mathrm{mol} / \mathrm{mol}, \mathrm{n}=47)$, which covers the full range of $\mathrm{Ba} / \mathrm{Ca}$ values encountered in this study (see results). Accuracy was assessed using MACS2; as there is no recommended value available for MACS2, we used our own SN-HR-ICP-MS data (MACS2 $=0.90 \pm 0.07 \mu \mathrm{mol} / \mathrm{mol}(\mathrm{n}=5)$, which indicate a robust LA-ICP-MS calibration. Details of operating conditions can 
330 be found in Lazareth et al. (2003). Briefly, the system consists of a Fisons-VG frequency quadrupled Nd-YAG laser (266 nm) coupled to a Fisons-VG PlasmaQuad II+ mass spectrometer.

The background or baseline $[\mathrm{Ba} / \mathrm{Ca}]_{\text {shell }}$ was selected by first omitting obvious peaks (e.g., $\sim 15-22 \mathrm{~mm}$ from the umbo in shell KN200203), then omitting all data that was

335 greater than $50 \%$ of the (peak-less) mean. This was repeated until the change in mean $[\mathrm{Ba} / \mathrm{Ca}]_{\text {shell }}$ was less than $5 \%$. This provided an objective criterion for selecting background $[\mathrm{Ba} / \mathrm{Ca}]_{\text {shell }}$ data.

\section{RESULTS}

340

\subsection{Laboratory experiments}

\subsubsection{Hemolymph}

345 In the dissolved $\mathrm{Ba}$ experiment, Mytilus edulis $[\mathrm{Ba} / \mathrm{Ca}]_{\text {hemolymph }}$ was only slightly different from the $[\mathrm{Ba} / \mathrm{Ca}]_{\text {water, }}$ with the linear least squares regression

$[\mathrm{Ba} / \mathrm{Ca}]_{\text {hemolymph }}=0.86( \pm 0.04) *[\mathrm{Ba} / \mathrm{Ca}]_{\text {water }}+2.26( \pm 1.49)$

350 (in $\mu \mathrm{mol} / \mathrm{mol} ; \mathrm{R}^{2}=0.98, \mathrm{p}<0.0001, \mathrm{n}=36$, in four treatments) (Fig 2, Table EA1). The errors of the regression coefficients reported above (and hereafter) represent the $95 \%$ confidence intervals $(95 \% \mathrm{CI})$, and are based on among individual variation and not among treatment variation. Despite the Ba difference in foods offered (3.35, 5.87 and $14.56 \mathrm{nmol} \mathrm{g}^{-1} \mathrm{DW} \mathrm{Ba}$ ), hemolymph was similar between the three 355 treatments of the feeding experiment (Fig. 2, inset; Table EA1).

\subsubsection{Tissues}

In the dissolved $\mathrm{Ba}$ experiment, tissue $\mathrm{Ba} / \mathrm{Ca}$ was slightly enriched as compared to $360[\mathrm{Ba} / \mathrm{Ca}]_{\text {water }}$ in the ambient treatment but was reduced by almost half in the highest $[\mathrm{Ba} / \mathrm{Ca}]_{\text {water }}$ treatment (Fig. 3). This resulted in an exponential fit between water and tissue 
$[\mathrm{Ba} / \mathrm{Ca}]_{\mathrm{tissue}}=35.36( \pm 2.19) *\left(1-\exp ^{(-0.07( \pm 0.01) *[\mathrm{Ba} / \mathrm{Ca}] \mathrm{water})}\right)$

365

(in $\mu \mathrm{mol} / \mathrm{mol}$; $\mathrm{R}^{2}=0.99, \mathrm{p}<0.0001, \mathrm{n}=11$, in four treatments) (Fig. 3, Table EA1). Although we do not have enough data for statistics, it is clear that there is a trend of increasing tissue $\mathrm{Ba} / \mathrm{Ca}$ with increasing food $\mathrm{Ba}$ (Fig. 3, inset; Table EA1) in the feeding experiment.

\subsubsection{Shells}

Between six to nine shells were analyzed for each Ba treatment (see Table EA1). In the dissolved $\mathrm{Ba}$ experiment, $[\mathrm{Ba} / \mathrm{Ca}]_{\text {shell }}$ was directly proportional to $[\mathrm{Ba} / \mathrm{Ca}]_{\text {water }}$ with 375 the linear relationship

$[\mathrm{Ba} / \mathrm{Ca}]_{\text {shell }}=0.10( \pm 0.02) *[\mathrm{Ba} / \mathrm{Ca}]_{\mathrm{water}}+1.00( \pm 0.68)$

(in $\mu \mathrm{mol} / \mathrm{mol} ; \mathrm{R}^{2}=0.84, \mathrm{p}<0.0001, \mathrm{n}=28$, in four treatments) (Fig 4, Table EA1). 380 To calculate the partition coefficient $\left(\mathrm{D}_{\mathrm{Ba}}\right)$, many studies force the regression through zero (see Lea and Spero, 1992; Zacherl et al., 2003); yet, considering that our intercept is well above zero, we chose not to force through the origin, resulting in a $\mathrm{D}_{\mathrm{Ba}}$ of $0.10 \pm 0.02(95 \% \mathrm{CI})$. However, it should be noted here that forcing through the origin does not significantly change the $\mathrm{D}_{\mathrm{Ba}}(0.12 \pm 0.01 ; 95 \% \mathrm{CI})(\mathrm{t}$-test, $\mathrm{p}=$ $3850.38)$.

Although shells were collected in early March, prior to the onset of the spring phytoplankton bloom (see further) and formation of the shell $\mathrm{Ba} / \mathrm{Ca}$ peak, we analyzed a few shells just behind the calcein mark to assess if the shells were 390 collected during the formation of a ' $\mathrm{Ba} / \mathrm{Ca}$ peak', but these shell regions did not exhibit elevated $[\mathrm{Ba} / \mathrm{Ca}]_{\text {shell }}$ indicative of the $\mathrm{Ba} / \mathrm{Ca}$ peak.

\subsection{Field experiment}


All four sites had significantly different salinity and $[\mathrm{Ba} / \mathrm{Ca}]_{\text {water }}$ values (Fig. 5A, B; ANOVA, $\mathrm{p}<0.0001$; post hoc LSD test, all $\mathrm{p}<0.01$; Table EA2) and there was a highly significant negative relationship between $[\mathrm{Ba} / \mathrm{Ca}]_{\text {water }}$ and salinity (Fig. 6; in $\mu \mathrm{mol} / \mathrm{mol} ; \mathrm{R}^{2}=0.73, \mathrm{n}=55, \mathrm{p}<0.0001$ ) with the linear relationship

$$
[\mathrm{Ba} / \mathrm{Ca}]_{\text {water }}=-1.22( \pm 0.21) * \text { Salinity }+46.05( \pm 4.57)
$$

The large scatter in these data is undoubtedly due to changes in the effective river end member as was previously demonstrated for the Schelde estuary (Coffey et al., 1997). There was no overall difference between $\mathrm{Chl}$ a concentrations at any of the stations (ANOVA, $p=0.43$ ), with the phytoplankton bloom starting in April and ending in late summer at all sites (Fig. 5C). The temperature profiles from the four sites were remarkably similar, with an annual range of 0 to $20^{\circ} \mathrm{C}$ (data not shown).

\subsubsection{Shells}

For the six shells analyzed, $\delta^{18} \mathrm{O}, \delta^{13} \mathrm{C}$ and $[\mathrm{Ba} / \mathrm{Ca}]_{\text {shell }}$ profiles are plotted against distance from the umbo in Fig. 7. All profiles are characterized by the typical low 415 level background $[\mathrm{Ba} / \mathrm{Ca}]_{\text {shell, }}$, interrupted by sharp episodic peaks (aside from one shell from OS, Fig. 7). Using the inverted $\delta^{18} \mathrm{O}$ scale as a temperature and season indicator (i.e., positive $\delta^{18} \mathrm{O}$ in winter), it is clear that these Ba peaks in the shell occur during spring when SST started to rise. The two shells which were transplanted from the Oosterschelde (sites HF and GR) showed clear calcein marks in their shells, which coincided with abrupt changes in the stable isotope profiles. The change in the $\delta^{13} \mathrm{C}$ profile is most pronounced in the GR shell as this site has a much lower salinity (Fig. 5B) and hence more a negative $\delta^{13} \mathrm{C}$ of dissolved inorganic carbon (DIC), compared to the Oosterschelde, where these animals were collected.

425 After selecting only the background $[\mathrm{Ba} / \mathrm{Ca}]_{\text {shell }}$ data from the shells (filled circles in Fig. 7, Table EA2), there was a highly significant linear relationship between background $[\mathrm{Ba} / \mathrm{Ca}]_{\text {shell }}$ and average $[\mathrm{Ba} / \mathrm{Ca}]_{\text {water }}$ data from the whole year:

$$
\text { background }[\mathrm{Ba} / \mathrm{Ca}]_{\text {shell }}=0.071( \pm 0.001) *[\mathrm{Ba} / \mathrm{Ca}]_{\text {water }}
$$


(in $\mu \mathrm{mol} / \mathrm{mol} ; \mathrm{R}^{2}=0.96, \mathrm{p}<0.0001, \mathrm{n}=233$ [data of 6 shells from 4 sites]). As opposed to the laboratory data, these data do include zero in the intercept, which was found to be not significant $(\mathrm{p}=0.79 ; 95 \%$ CI range $=-0.16$ to +0.12$)$ and was therefore not included in the regression. Thus the $\mathrm{D}_{\mathrm{Ba}}$ determined from the field experiment is 0.071 ( \pm 0.001$)$, which is significantly different from the $D_{\mathrm{Ba}}$ determined in the laboratory (Fig. 8; t-test, $\mathrm{p}<0.001$ ).

\section{DISCUSSION}

\subsection{Pathway of barium incorporation into the shell}

Biomineralization in bivalves takes place in the extrapallial fluid (EPF), a thin film of liquid between the calcifying shell surface and the mantle epithelium (Wheeler, 1992). The central EPF is where the inner aragonite shell layer is precipitated, 445 whereas the outer calcite shell layer is precipitated from the marginal EPF (i.e., the layer analyzed in this study). The EPF is isolated from seawater and therefore may have different elemental concentrations than seawater. Although there are numerous reports on central EPF elemental concentrations (e.g., Crenshaw, 1972; Wada and Fujinuki, 1976), direct measurements of the marginal EPF are difficult and we know

450 of only one report providing marginal EPF elemental concentrations, but unfortunately Ba was not measured (Lorens, 1978). However, there does not seem to be a difference in Ba concentrations between hemolymph and central EPF in other bivalve species (A. Lorrain, unpublished data).

455 Elements move into the EPF through the epithelial mantle cells which are supplied from the hemolymph (Wilbur and Saleuddin, 1983). Ions enter the hemolymph of marine mollusks primarily through the gills, although they may also enter via the gut (see Wilbur and Saleuddin, 1983 and references therein). The relative contributions of $\mathrm{Ba}$ to the shell from food versus environment are unknown; however, mollusk guts are known to contain high $\mathrm{Ba}$ concentrations (Lobel et al., 1991; A. Lorrain, unpublished data). Therefore, it is possible that the gut is a source of $\mathrm{Ba}$ in mollusk shells. However, if food $\mathrm{Ba}$ impacted background $[\mathrm{Ba} / \mathrm{Ca}]_{\text {shell, }}$, the regression between background $[\mathrm{Ba} / \mathrm{Ca}]_{\text {shell }}$ and $[\mathrm{Ba} / \mathrm{Ca}]_{\text {water }}$ would not go through zero (meaning zero $[\mathrm{Ba} / \mathrm{Ca}]_{\text {water }}=$ zero $\left.[\mathrm{Ba} / \mathrm{Ca}]_{\text {shell }}\right)$. In the field specimens, the regression does go through 
465 zero (Fig. 8). This, together with the good correlation with $[\mathrm{Ba} / \mathrm{Ca}]_{\text {water, }}$, makes it very unlikely that food is a major source of $\mathrm{Ba}$ to the shell during those times when background $[\mathrm{Ba} / \mathrm{Ca}]_{\text {shell }}$ is observed. Nevertheless ingested particulate $\mathrm{Ba}$ may be involved in the formation of the $[\mathrm{Ba} / \mathrm{Ca}]_{\text {shell }}$ peaks (see section 4.3 ).

\subsection{Mytilus edulis calcite $\mathrm{D}_{\mathrm{Ba}}$}

Both the laboratory and field experiments verify that there is a direct relationship between background $[\mathrm{Ba} / \mathrm{Ca}]_{\text {shell }}$ and $[\mathrm{Ba} / \mathrm{Ca}]_{\text {water }}$ in $M$. edulis calcite. A possible reason for the difference in slopes between the laboratory and field experiment

$475[\mathrm{Ba} / \mathrm{Ca}]_{\text {shell }}$ vs. $[\mathrm{Ba} / \mathrm{Ca}]_{\text {water }}$ (Fig. 8) may be that we did not replicate treatments in the laboratory, but only individuals within a treatment, while we had an overall low number of samples form the field experiment. An alternative explanation could be that the stress of handling and the suddenly increased $\mathrm{Ba}$ concentration in the laboratory experiments caused a saturation of the ionoregulatory ability of the animal.

480 Lorens and Bender (1980) found that elemental ratios in shells increased in laboratory held M. edulis for a short while, then decreased (they termed this section of the shell "transition zone calcite" (or TZC)). They proposed that this was caused by the stress of capture and the adjustment to a new environment. Although we acclimated these animals to laboratory conditions for three weeks, the change to the experimental conditions may have caused stress and we may have included TZC in our analyses. This could explain the higher $\mathrm{D}_{\mathrm{Ba}}$ in the laboratory cultured mussels. Furthermore, the fact that the regression does not go through the origin supports this. As in the field population, it can be expected that when there is zero $\mathrm{Ba}$ in the water, there should be zero $\mathrm{Ba}$ in the shell. Interestingly, as the hemolymph can be expected to represent the crystallization fluid better than seawater, when a regression between hemolymph and shell is performed (laboratory experiment), the regression does go through the origin (intercept not significant, $\mathrm{p}=0.07)$. The $\mathrm{D}_{\mathrm{Ba}}$ calculated using hemolymph, $0.134( \pm$ 0.006) $\left(\mathrm{R}^{2}=0.95, \mathrm{n}=25, \mathrm{p}<0.0001\right)$, is also more similar to that for planktonic foraminifera (see further).

Alternatively, the field $\mathrm{D}_{\mathrm{Ba}}$ may also not be accurate, we averaged the $[\mathrm{Ba} / \mathrm{Ca}]_{\text {water }}$ from the whole year, while it is clear that the background $[\mathrm{Ba} / \mathrm{Ca}]_{\text {shell }}$ is formed from approximately mid-summer to the end of the growing season. Selecting only the 
$[\mathrm{Ba} / \mathrm{Ca}]_{\text {water }}$ from July to November changes the regression slightly, but significantly to background $[\mathrm{Ba} / \mathrm{Ca}]_{\text {shell }}=0.091( \pm 0.006) *[\mathrm{Ba} / \mathrm{Ca}]_{\text {water }}-0.52( \pm 0.17)\left(\mathrm{R}^{2}=0.76\right.$, $\mathrm{p}<0.0001$ ), and when only selecting September to November it changes to background $[\mathrm{Ba} / \mathrm{Ca}]_{\text {shell }}=0.081( \pm 0.006) *[\mathrm{Ba} / \mathrm{Ca}]_{\text {water }}-0.26( \pm 0.15)\left(\mathrm{R}^{2}=0.76, \mathrm{p}\right.$ $<0.0001)$. Therefore, considering both the laboratory and field data, we propose that the $\mathrm{D}_{\mathrm{Ba}}$ for M. edulis lies within the range of 0.07 to 0.12 . Furthermore, the algorithm 505 used to select the background $[\mathrm{Ba} / \mathrm{Ca}]_{\text {shell }}$ data used here may be excluding some $[\mathrm{Ba} / \mathrm{Ca}]_{\text {water }}$ data stored in the shell. It is possible that all $[\mathrm{Ba} / \mathrm{Ca}]_{\text {shell }}$ data between large $[\mathrm{Ba} / \mathrm{Ca}]_{\text {shell }}$ peaks are recording $[\mathrm{Ba} / \mathrm{Ca}]_{\text {water. }}$. If this was the case, seasonal $[\mathrm{Ba} / \mathrm{Ca}]_{\text {water }}$ could be reconstructed; however, this could only be determined from more detailed experiments. Nevertheless, these data do illustrate that average $510[\mathrm{Ba} / \mathrm{Ca}]_{\text {water }}$ can be estimated from M. edulis shells using the proposed algorithm to select the background $[\mathrm{Ba} / \mathrm{Ca}]_{\text {shell }}$ data.

It should be noted that incorporation of elements in calcite with ionic radii larger than calcium (such as $\mathrm{Ba}$ ) are expected to be strongly affected by external factors, such as 515 temperature or salinity (Pingitore and Eastman, 1984; Morse and Bender, 1990). We are unable to determine if salinity has an effect or not. The strong relationship in the field between $[\mathrm{Ba} / \mathrm{Ca}]_{\text {water }}$ and salinity makes it difficult to deconvolve the effects, whereas in the laboratory salinity was similar in all treatments. Therefore, this could be another reason for the difference in intercepts between the two experiments.

520 Considering the seasonal $20{ }^{\circ} \mathrm{C}$ temperature range at these sites (from $\sim 0$ to $20{ }^{\circ} \mathrm{C}$ ), and the stable background $[\mathrm{Ba} / \mathrm{Ca}]$ ratios observed in these shells, it does not seem likely that there is a major temperature effect on background $\mathrm{D}_{\mathrm{Ba}}$ in M. edulis. This is most probably true for all bivalves as well, as the stable Ba background in all published data is evident and temperature almost always has a seasonal cyclicity.

525 Similarly, Lea and Spero (1994) did not find an influence of temperature on $\mathrm{D}_{\mathrm{Ba}}$ in foraminifera, and no temperature effect has been reported for inorganic calcite. However, definitive experiments should be carried out to confirm that temperature does not affect bivalve background $[\mathrm{Ba} / \mathrm{Ca}]$ ratios.

530 Abiogenic experiments on the $\mathrm{D}_{\mathrm{Ba}}$ in calcite have provided a range of values, which is probably due to unconstrained precipitation rates in many of the experiments (Tesoriero and Pankow, 1996). For the range of M. edulis shell precipitation rates 
estimated by Lorens (1981), $\mathrm{D}_{\mathrm{Ba}}$ is expected to range between 0.03 and 0.05 according to the abiogenic calcite experiments of Tesoriero and Pankow (1996).

535 Pingitore and Eastman (1984) provided an inorganic $\mathrm{D}_{\mathrm{Ba}}$ of $0.06 \pm 0.01$, which is very similar to the low end of the range we estimate for M. edulis $\mathrm{D}_{\mathrm{Ba}}$ (i.e., 0.07). Planktonic foraminifera, on the other hand can have higher $\mathrm{D}_{\mathrm{Ba}}$ than M. edulis, ranging from 0.09 to 0.19 (Lea and Boyle, 1991; Lea and Spero, 1992; 1994), whereas benthic foraminifera have an even higher $\mathrm{D}_{\mathrm{Ba}}$ in both laboratory $(0.2-0.5$;

540 Havach et al., 2001) and field based studies (0.37; Lea and Boyle, 1989). It can generally be considered that when the partition coefficient of a particular element $\left(D_{\mathrm{Me}}\right)$ is far from inorganically determined $\mathrm{D}_{\mathrm{Me}}$, then other factors most likely influence $\mathrm{D}_{\mathrm{Me}}$, such as the physiology of the organism or other biological factors. For example, $\mathrm{Sr} / \mathrm{Ca}$ in corals has been shown to be a good SST proxy and the $\mathrm{D}_{\mathrm{Sr}}$ is close to one (Weber, 1973), which is similar to abiogenic aragonite (Kinsman and Holland, 1969), whereas in aragonitic bivalve shells the $D_{S r}$ is around 0.25 and there is no link with SST (Gillikin et al., 2005a). The fact that foraminiferal $\mathrm{Ba} / \mathrm{Ca}$ has successfully been used as a proxy of dissolved $\mathrm{Ba} / \mathrm{Ca}$, and that the foraminiferal $\mathrm{D}_{\mathrm{Ba}}$ is farther from expected values than $M$. edulis, further implies that $\mathrm{Ba} / \mathrm{Ca}$ in $M$. edulis has great

550 potential as a robust proxy of dissolved seawater $\mathrm{Ba} / \mathrm{Ca}$, as there should be an even smaller biological effect in M. edulis calcite.

To test this proxy further, we use the shell GR210403 data for the period preceding transplantation. These data should be representative of Oosterschelde conditions with

555 salinity above 30 (see section 2.2). The background $[\mathrm{Ba} / \mathrm{Ca}]_{\text {shell }}$ before transplantation is $0.98 \pm 0.05(\mathrm{n}=13)$, which corresponds to a $[\mathrm{Ba} / \mathrm{Ca}]_{\text {water }}$ of $13.8 \pm 0.7$ when using a $\mathrm{D}_{\mathrm{Ba}}$ of 0.07 and $8.2 \pm 0.4$ when using a $\mathrm{D}_{\mathrm{Ba}}$ of 0.12 . A range of $[\mathrm{Ba} / \mathrm{Ca}]_{\text {water }}$ of 8 to 14 is reasonable for a salinity of about 30 (Fig. 6) and provides additional evidence that even at low $[\mathrm{Ba} / \mathrm{Ca}]_{\text {water, }}$ this is a good proxy.

\subsection{High resolution barium profiles}

Our results confirm the general Ba profiles recorded in other bivalves (e.g., Stecher et al., 1996; Toland et al., 2000; Vander Putten et al., 2000; Torres et al., 2001; Lorrain, 565 2002; Lazareth et al., 2003; Gillikin, 2005), with a stable background signal interrupted by sharp episodic peaks, generally occurring in the spring (using $\delta^{18} \mathrm{O}$ as a 
relative temperature scale). The unstable background $\mathrm{Ba}$ in OS shells probably reflects the highly variable salinity at this site. Another striking feature of the profiles is that the peak amplitude seems to be correlated to the mussels' age, with younger shell sections having larger peaks. For example, shell KN200203 has a large Ba/Ca peak $\sim 20 \mu \mathrm{mol} / \mathrm{mol}$ at $15-22 \mathrm{~mm}$ of growth, while in the same shell at $38-40 \mathrm{~mm}$ the peak only reaches $\sim 5 \mu \mathrm{mol} / \mathrm{mol}$ (Fig. 7). This is reproduced in the other shells as well, with a large peak around $24 \mathrm{~mm}$ in shell GR210403 and small peaks around 35 - 40 mm in shells KN9 290902 and HF091202 (Fig. 7). This trend was also found by 575 Vander Putten et al. (2000), who collected their M. edulis shells from the same estuary in 1997, suggesting that peak amplitude is not environmentally controlled. However, this could be an averaging effect, with the sample size integrating more growth time as shell growth slows with age (see Goodwin et al., 2001). Considering the width of the peaks, this does not seem probable and is more likely a physiological effect of ageing (see further).

There are several hypotheses which could explain the $[\mathrm{Ba} / \mathrm{Ca}]_{\text {shell }}$ peaks. The hypothesis of Stecher et al. (1996), that either Ba-rich phytoplankton or barite formed in decaying phytoplankton flocs are ingested by the filter feeding bivalve and 585 eventually the $\mathrm{Ba}$ is sequestered in the shell, is plausible. However, our data do not support a direct incorporation of $\mathrm{Ba}$ from phytoplankton ingestion into the shell. Although we could not measure $\mathrm{Ba}$ in the shell in the feeding experiment, it can be assumed that ingested $\mathrm{Ba}$ would have to pass through the hemolymph to get to the EPF and be taken up in the shell (see section 4.1). We fed mussels food with different

590 Ba concentrations, which was taken up in the bulk tissues (Fig. 3 inset), but hemolymph Ba concentrations did not increase (Fig. 2 inset). However, it is possible that $\mathrm{Ba}$ concentrations in the food offered in this study were not high enough to have an effect (maximum $\sim 15 \mathrm{nmol} / \mathrm{g}$ ). Although many marine phytoplankton species contain barium concentrations similar to that of the food used in this study, certain 595 species can have barium concentrations as high as $420 \mathrm{nmol} / \mathrm{g}$ (dry weight; Dehairs et al., 1980) (see Fisher et al. (1991) for review). Therefore, as previously suggested by Stecher et al. (1996), the $[\mathrm{Ba} / \mathrm{Ca}]_{\text {shell }}$ peaks can still be related to phytoplanktonic events in some way; for example, barite ingestion (see further) or uptake of specific phytoplankton species containing high levels of barium. However, the lack of a $600[\mathrm{Ba} / \mathrm{Ca}]_{\text {shell }}$ peak in the shell OS 091202 (Fig. 7) and the large Chl a peak at this site 
(Fig. 5C) suggest that phytoplankton blooms are not the direct cause. Nevertheless, this does not exclude barite ingestion as a cause. Indeed, invertebrates are known to directly ingest barite crystals (Brannon and Rao, 1979). It is possible that barite formation only occurs downstream from the OS site (see Stecher and Kogut, 1999), explaining the lack of a $[\mathrm{Ba} / \mathrm{Ca}]_{\text {shell }}$ peak at this site. This would also explain the large sharp $[\mathrm{Ba} / \mathrm{Ca}]_{\text {shell }}$ peak in the $\mathrm{KN}$ shells (Fig. 7), despite the lower broad $\mathrm{Chl}$ a peak at this site (Fig. 5C). However, particulate Ba data from the Schelde, which show a peak in the spring only at mid-salinities (Zwolsman and van Eck, 1999), do not agree with this scenario; but a more detailed sampling campaign is needed to be conclusive.

610 Clearly, more work is needed to understand the relationship between these $[\mathrm{Ba} / \mathrm{Ca}]_{\text {shell }}$ peaks and phytoplankton. Therefore, further experiments for longer time periods using a larger range of $[\mathrm{Ba}]$ in food and possibly even barite would be useful.

An increase in $[\mathrm{Ba} / \mathrm{Ca}]_{\text {water }}$ is highly unlikely to be the cause of $[\mathrm{Ba} / \mathrm{Ca}]_{\text {shell }}$ peaks, as 615 the $20-25 \mu \mathrm{mol} / \mathrm{mol}[\mathrm{Ba} / \mathrm{Ca}]_{\text {shell }}$ peaks would require $[\mathrm{Ba} / \mathrm{Ca}]_{\text {water }}$ to be around 300 $\mu \mathrm{mol} / \mathrm{mol}$, which is clearly not the case (Fig 5A). An alternative hypothesis may be that $\mathrm{Ba}$ is remobilized from tissue stores during spawning, which also occurs in the spring. Indeed, M. edulis tissue dry weight also exhibits sharp episodic peaks throughout the life of the animal (Kautsky, 1982). The lack of a $[\mathrm{Ba} / \mathrm{Ca}]_{\text {shell }}$ peak in 620 the OS shell could possibly be due to this mussel not spawning. Osmotic stress may have required a large part of this animals' energy budget, leaving no energy for spawning (cf. Qiu et al., 2002; Gillikin et al., 2004). It is also interesting to note that the $\delta^{13} \mathrm{C}$ profiles coincide with changes in $[\mathrm{Ba} / \mathrm{Ca}]_{\text {shell. }}$ This is most evident in shells KN9 290902 and HF092102, where the $\delta^{13} \mathrm{C}$ values are more negative when the $625[\mathrm{Ba} / \mathrm{Ca}]_{\text {shell }}$ deviates from background concentrations and are more positive when the $[\mathrm{Ba} / \mathrm{Ca}]_{\text {shell }}$ is at background levels (Fig. 7). Bivalve shell $\delta^{13} \mathrm{C}$ values are known to be influenced by the incorporation of metabolically derived light carbon (i.e., ${ }^{12} \mathrm{C}$ ) (McConnaughey et al., 1997). Furthermore, it has been shown that increased metabolism in larger bivalves, relative to growth rate, leads to a larger availability of metabolic $\mathrm{C}$ for $\mathrm{CaCO}_{3}$ precipitation and therefore results in a more negative $\delta^{13} \mathrm{C}$ in the shell (Lorrain et al., 2004). Using this rationale, higher metabolic rates from either spawning or seasonally increased growth, caused by an increase in food supply, would also result in a more negative shell $\delta^{13} \mathrm{C}$. This could explain the pattern we see in these shells, and also agrees with a metabolic control on $[\mathrm{Ba} / \mathrm{Ca}]_{\text {shell }}$ peak amplitude 
635 as described above. However, data from the scallop, Pecten maximus, do not corroborate this hypothesis, with their $[\mathrm{Ba} / \mathrm{Ca}]_{\text {shell }}$ peaks not being correlated with spawning (Lorrain, 2002). Alternatively, the higher $[\mathrm{Ba} / \mathrm{Ca}]_{\text {shell }}$ could be a kinetic growth rate effect, which has been noted in inorganic calcite (Tesoriero and Pankow, 1996). Higher growth rates would also increase metabolic rates and thus lower shell

$640 \delta^{13} \mathrm{C}$. Finally, it can be argued that the $[\mathrm{Ba} / \mathrm{Ca}]_{\text {shell }}$ peaks can be caused by higher organic matter content in the shell. Bivalve shells can contain up to $5 \%$ organic matter (see Marin and Luquet, 2004, and references therein) and $\mathrm{Ba}$ is known to be associated with organic matter (Lea and Boyle, 1993). However, neither Hart et al. (1997) nor Sinclair (2005) found a relationship between organic matter and $\mathrm{Ba}$ 645 concentrations in other biogenic carbonates (i.e., corals), and Rosenthal and Katz (1989) suggest that $\mathrm{Ba}$ is bound to the crystal in mollusks. Thus it is unlikely that the Ba peaks are associated with shell regions containing higher organic content.

Remarkably, a similar phenomenon also occurs in corals, with sharp episodic Ba

650 peaks occurring at the same time each year, which are not related to river discharge (Sinclair, 2005). However, unlike bivalves, Sinclair (2005) found that the timing of the peaks differed between coral colonies, even when they grew within $20 \mathrm{~km}$ of each other. The main conclusion of Sinclair (2005) regarding the cause of these peaks in corals was that there is currently no satisfactory hypothesis to explain them. This is 655 also the case for bivalves. However, the similarities between coral and bivalve $\mathrm{Ba} / \mathrm{Ca}$ peaks may suggest a common cause for these peaks. This in itself would be amazing considering the large difference in biology, ecology, and biomineralization mechanisms between these two phyla of invertebrates.

\subsection{Implications for estuarine paleo-seawater chemistry}

Our data suggest that M. edulis shells have potential as a proxy of dissolved $[\mathrm{Ba} / \mathrm{Ca}]_{\text {water. }}$ However, it should be clear that only high resolution profiles covering an adequate amount of growth may be used to assure the correct background $[\mathrm{Ba} / \mathrm{Ca}]_{\text {shell }}$

665 is selected. This selection can also be aided using the $\delta^{18} \mathrm{O}$ and $\delta^{13} \mathrm{C}$ profiles. Selecting the mid-summer growth region (or the most negative $\delta^{18} \mathrm{O}$ ) along with the most positive $\delta^{13} \mathrm{C}$ should result in a good selection of background $[\mathrm{Ba} / \mathrm{Ca}]_{\text {shell. }}$ Obviously whole shell analyses are not suitable to determine $[\mathrm{Ba} / \mathrm{Ca}]_{\text {water }}$, because peaks would 
be integrated. Once the correct background $[\mathrm{Ba} / \mathrm{Ca}]_{\text {shell }}$ is obtained, the $[\mathrm{Ba} / \mathrm{Ca}]_{\text {water }}$ may be approximated using a $\mathrm{D}_{\mathrm{Ba}}$ of about 0.1 . These data can be useful for giving a relative indication of salinity (different estuaries can be expected to have different salinity - $[\mathrm{Ba} / \mathrm{Ca}]_{\text {water }}$ relationships (Coffey et al., 1997)), which could assist with $\delta^{18} \mathrm{O}$ interpretations (see Gillikin et al., 2005b for more explanation). Furthermore, if $[\mathrm{Ba} / \mathrm{Ca}]_{\text {water }}$ was extended back through geologic time for the world's large estuaries,

675 the overall change in the oceanic Ba budget could be better constrained. However, we stress that this proxy needs to be further refined before it should be used as a proxy of environmental conditions.

\section{SUMMARY}

680

In both the field and laboratory we have verified that background $\mathrm{Ba} / \mathrm{Ca}$ ratios in Mytilus edulis shells are directly related to the $\mathrm{Ba} / \mathrm{Ca}$ ratios of the water in which they grew. Our data suggest that the $\mathrm{D}_{\mathrm{Ba}}$ of $M$. edulis calcite is within the range of 0.07 to 0.12 , which is very close to the expected $\mathrm{D}_{\mathrm{Ba}}$ range determined from inorganic calcite 685 studies (0.03 to 0.07; Pingitore and Eastman, 1984; Tesoriero and Pankow, 1996) and is lower than foraminiferal calcite (see previous references). Although our laboratory data on the effect of $\mathrm{Ba}$ in food was inconclusive, they, along with data from the field, suggest that the nearly ubiquitous $\mathrm{Ba} / \mathrm{Ca}$ peaks found in bivalve shells are not related to phytoplankton blooms in a simple manner, but might be related to barite ingestion.

690 Finally, the $\mathrm{Ba} / \mathrm{Ca}$ (background) proxy in bivalve shells can be used as a relative indicator of salinity, and if better constrained, can extend our knowledge of estuarine Ba cycling back through time by using fossil or archaeological shells.

Acknowledgements - We thank P. Dubois and H. Ranner (Université Libre de 695 Bruxelles) for the use of their cold room and assistance with the laboratory experiment. V. Mubiana (U. Antwerp) kindly assisted with mussel collection, gave advice on mussel husbandry and helped setting up the field experiment and acid digesting the tissue samples. We also thank A. Van de Maele and M. Korntheuer for technical support with the IRMS and L. Monin and J. Navez for laboratory (ICP)

700 assistance. We are grateful for the HPLC expertise offered by J. Sinke and J. Nieuwenhuize (NIOO-CEME, Yerseke, NL). H.A. Stecher, D.W. Lea (associate editor), two anonymous reviewers, A. Verheyden and S. Bouillon gave helpful 
comments on an earlier version of this manuscript; M. Elskens assisted with statistics and together with N. Brion collected the North Sea water. Funding was provided by both the Belgian Federal Science Policy Office, Brussels, Belgium (CALMARS, contract: EV/03/04B) and the ESF Paleosalt project funded by the FWO-Flanders (contract: G.0642.05). Funding for the HR-ICP-MS equipment was partly provided via the Belgian Lotto and FWO-Flanders (contract: G.0117.02N).

\section{References}

Baeyens W., van Eck B., Lambert C., Wollast R., and Goeyens L. (1998) General description of the Scheldt estuary. Hydrobiologia 366, 1-14.

Blust R, Vanderlinden A., Verheyen E., and Decleir W. (1988) Evaluation of microwave-

715 heating digestion and graphite-furnace atomic-absorption spectrometry with continuum source background correction for the determination of iron, copper and cadmium in brine shrimp. J. Anal. Atom. Spectrom. 3, 387-393.

Brannon A. C., and Rao K. R. (1979) Barium, strontium and calcium levels in the exoskeleton, hepatopancreas and abdominal muscle of the grass shrimp, Palaemonetes

720 pugio - relation to molting and exposure to barite. Comparative Biochemistry and Physiology A-Physiology 63, 261-274.

Buckel J. A., Sharack B. L., and Zdanowicz V. S. (2004) Effect of diet on otolith composition in Pomatomus saltatrix, an estuarine piscivore. J. Fish Biol. 64, 1469-1484.

Carroll J., Falkner K. K., Brown E. T., and Moore W. S. (1993) The role of the Ganges-

725 Brahmaputra mixing zone in supplying barium and Ra-226 to the Bay of Bengal. Geochim. Cosmochim. Acta 57, 2981-2990.

Chan L. H., Drummond D., Edmond J. M., and Grant B. (1977) On the barium data from the Atlantic GEOSECS expedition. Deep-Sea Res. 24, 613-649.

Coffey M., Dehairs F., Collette O., Luther G., Church T., and Jickells T. (1997) The behaviour of dissolved barium in estuaries. Est. Coast. Shelf Sci. 45, 113-121.

Crenshaw, M. A. (1972) Inorganic composition of molluscan extrapallial fluid, Biol. Bull., 143, 506-512.

Dehairs F., Baeyens W., and Goeyens L. (1992) Accumulation of suspended barite at mesopelagic depths and export production in the Southern Ocean. Science 258, 13327351335.

Dehairs F., Chesselet R., and Jedwab J. (1980) Discrete suspended particles of barite and the barium cycle in the open ocean. Earth Planet. Sci. Lett. 49, 528-550. 
Dehairs F., Lambert C. E., Chesselet R., and Risler N. (1987) The biological production of marine suspended barite and the barium cycle in the Western Mediterranean Sea.

740 Biogeochemistry 4, 119-139.

Dymond J., Suess E., and Lyle M. (1992) Barium in deep-sea sediment: A geochemical proxy for paleoproductivity. Paleoceanography 7, 163-181.

Edmond J. M., Boyle E. D., Drummond D., Grant B., Mislick T. (1978) Desorption of barium in the plume of the Zaire (Congo) River. Netherlands J. Sea Res. 12, 324-328.

745 Fisher N. S., Guillard R. R. L., and Bankston D. C. (1991) The accumulation of barium by marine-phytoplankton grown in culture. Journal of Marine Research 49: 339-354.

Freitas P., Clarke L. J., Kennedy H., Richardson C., and Abrantes F. (2005) Mg/Ca, $\mathrm{Sr} / \mathrm{Ca}$, and stable-isotope $\left(\delta^{18} \mathrm{O}\right.$ and $\left.\delta^{13} \mathrm{C}\right)$ ratio profiles from the fan mussel Pinna nobilis: Seasonal records and temperature relationships. Geochem. Geophy. Geosys. 6, Q04D14, 750 doi:10.1029/2004GC000872.

Gerringa L. J. A., Hummel H., and Moerdijk-Poortvliet T. C. W. (1998) Relations between free copper and salinity, dissolved and particulate organic carbon in the Oosterschelde and Westerschelde, Netherlands. J. Sea Res. 40, 193-203.

Gieskes W. W. C., Kraay G. W., Nontji A., Setiapennana D., and Sutomo (1988) Monsoonal 755 alternation of a mixed and layered structure in the phytoplankton of the euphotic zone of the Banda Sea (Indonesia), a mathematical analysis of algal pigment fingerprints. Neth. J. Sea Res. 22, 123-137.

Gillikin D. P., De Ridder F., Ulens H., Elskens M., Keppens E., Baeyens W., and Dehairs F. (2005b) Assessing the reproducibility and reliability of estuarine bivalve shells (Saxidomus 760 giganteus) for sea surface temperature reconstruction: implications for paleoclimate studies. Palaeogeogr. Palaeoclimatol. Palaeoecol. doi:10.1016/j.palaeo.2005.03.047

Gillikin D. P., Lorrain A., Navez J., Taylor J. W., André L., Keppens E., Baeyens W., and Dehairs F. (2005a) Strong biological controls on $\mathrm{Sr} / \mathrm{Ca}$ ratios in aragonitic marine bivalve shells. Geochem. Geophy. Geosys. 6, Q05009, doi:10.1029/2004GC000874.

765 Gillikin D.P., 2005. Geochemistry of Marine Bivalve Shells: the potential for paleoenvironmental reconstruction. Ph.D. thesis. Vrije Universiteit Brussel, Belgium.

Gillikin D.P., De Wachter B., and Tack J. F. (2004) Physiological responses of two ecologically important Kenyan mangrove crabs exposed to altered salinity regimes. J. Exp. Mar. Biol. Ecol. 301, 93-109.

770 Goodwin D. H., Flessa K. W., Schöne B. R., Dettman D. L. (2001) Cross-calibration of daily growth increments, stable isotope variation, and temperature in the Gulf of California bivalve mollusk Chione cortezi: implications for paleoenvironmental analysis. Palaios 16, 387-398. 
Guay C. K., and Falkner K. K. (1997) Barium as a tracer of Arctic halocline and river waters. Deep-Sea Res. II 44, 1543-1569.

Guay C. K., and Falkner K. K. (1998) A survey of dissolved barium in the estuaries of major Arctic rivers and adjacent seas. Cont. Shelf Res. 18, 859-882.

Hart S. R., Cohen A. L., and Ramsay P. (1997) Microscale analysis of $\mathrm{Sr} / \mathrm{Ca}$ and Ba/Ca in Porites, Proceedings of the $8^{\text {th }}$ International Coral Reef Symposium 2, 1707 - 1712.

780 Havach S. M., Chandler T., Wilson-Finelli A., and Shaw T. J. (2001) Experimental determination of trace element partition coefficients in cultured benthic foraminifera. Geochim. Cosmochim. Acta 65, 1277-1283.

Jacquet S. H. M., Dehairs F., Cardinal D., Navez J., and Delille B. (2005) Barium distribution across the Southern Ocean frontal system in the Crozet-Kerguelen Basin. Mar. Chem. 95, 149-162.

Kautsky N. (1982) Growth and size structure in a Baltic Mytilus edulis population. Mar. Biol. 68, 117-133.

Kinsman D. J. J., and Holland H. D. (1969) The co-precipitation of cations with $\mathrm{CaCO}_{3}$ - IV. the co-precipitation of $\mathrm{Sr}^{2+}$ with aragonite between 16 degrees and 96 degrees C. Geochim. $790 \quad$ Cosmochim. Acta 33, 1-17.

Klein R. T., Lohmann K. C., and Thayer C. W. (1996) Bivalve skeletons record sea-surface temperature and $\delta^{18} \mathrm{O}$ via $\mathrm{Mg} / \mathrm{Ca}$ and ${ }^{18} \mathrm{O} /{ }^{16} \mathrm{O}$ ratios. Geology 24, 415-418.

Lazareth C. E., Vander Putten E., André L., and Dehairs F. (2003) High-resolution trace element profiles in shells of the mangrove bivalve Isognomon ephippium: a record of environmental spatio-temporal variations? Est. Coast. Shelf Sci. 57, 1103-1114.

Lea D. W, and Spero H. J. (1992) Experimental determination of barium uptake in shells of the planktonic foraminifera Orbulina universa at $22^{\circ} \mathrm{C}$. Geochim. Cosmochim. Acta 56, 2673-2680.

Lea D. W, and Spero H. J. (1994) Assessing the reliability of paleochemical tracers: Barium uptake in the shells of planktonic foraminifera. Paleoceanography 9, 445-452.

Lea D. W. (1993) Constraints on the alkalinity and circulation of glacial circumpolar deepwater from benthic foraminiferal barium. Global Biogeochem. Cy. 7, 695-710.

Lea D. W., and Boyle E. (1989) Barium content of benthic foraminifera controlled by bottomwater composition. Nature 338, 751-753.

805 Lea D. W., and Boyle E. (1991) Barium in planktonic foraminifera. Geochim. Cosmochim. Acta 55, 3321-3331.

Lea D. W., and Boyle E. (1993) Determination of carbonate-bound barium in foraminifera and corals by isotope dilution plasma-mass spectrometry. Chem. Geol. 103, 73 - 84.

Lobel P. B., Longerich H. P., Jackson S. E., and Belkhode S. P. (1991) A major factor 810 contributing to the high degree of unexplained variability of some elements concentrations 
in biological tissue - 27 elements in 5 organs of the mussel Mytilus as a model. Arch. Environ. Con. Tox. 21, 118-125.

Lorens R. B. (1978) A study of biological and physiological controls on the trace metal content of calcite and aragonite. Ph.D. thesis, University of Rhode Island.

815 Lorens R. B. (1981) Sr, Cd, Mn and Co distribution coefficients in calcite as a function of calcite precipitation rate. Geochim. Cosmochim. Acta 45, 553-561.

Lorens R. B., and Bender M. L. (1980) The impact of solution chemistry on Mytilus edulis calcite and aragonite. Geochim. Cosmochim. Acta 44, 1265-1278.

Lorrain A. (2002) Utilisation de la coquille Saint-Jacques comme traceur environnemental:

820 approches biologique et biogéochimique. $\mathrm{PhD}$ thesis, Université de Bretagne occidentale, Brest, France.

Lorrain A., Paulet Y.-M., Chauvaud L., Dunbar R., Mucciarone D., and Fontugne M. (2004) $\delta^{13} \mathrm{C}$ variations in scallop shells: Increasing metabolic carbon contribution with body size? Geochim. Cosmochim. Acta 68, 3509-3519.

825 Lorrain A., Gillikin D.P., Paulet Y.-M., Chauvaud L., Le Mercier A., Navez J., and André L. (in press) Strong kinetic effects on $\mathrm{Sr} / \mathrm{Ca}$ ratios in the calcitic bivalve Pecten maximus. Geology, 1 December 2005 issue

Marin F., and Luquet G. (2004) Molluscan shell proteins. C. R. Palevol 3, 469-492.

McConnaughey T. A., Burdett J., Whelan J. F., and Paull C. K. (1997) Carbon isotopes in

830 biological carbonates: Respiration and photosynthesis. Geochim. Cosmochim. Acta 61, 611-622.

McCulloch M., Fallon S., Wyndham T., Hendy E., Lough J., and Barnes D. (2003) Coral record of increased sediment flux to the inner Great Barrier Reef since European settlement. Nature 421, 727-730.

835 McManus J., Berelson W. M., Hammond D. E., and Klinkhammer G. P. (1999) Barium cycling in the North Pacific: Implications for the utility of $\mathrm{Ba}$ as a paleoproductivity and paleoalkalinity proxy. Paleoceanography 14, 53-61.

McManus J., Dymond J., Dunbar R. B., and Collier R. W. (2002) Particulate barium fluxes in the Ross Sea. Mar. Geol. 184, 1-15.

840 Moore W. S., and Edmond J. M. (1984) Radium and barium in the Amazon River system. $J$. Geophys. Res. Oceans 89 (NC2), 2061-2065.

Morse J. W., and Bender M. L. (1990) Partition-coefficients in calcite - examination of factors influencing the validity of experimental results and their application to natural systems. Chem. Geol. 82, 265-277.

845 Paytan A., and Kastner M. (1996) Benthic Ba fluxes in the central Equatorial Pacific, implications for the oceanic Ba cycle. Earth Planet. Sci. Lett.142, 439-450. 
Pearce N. J. G., Perkins W. T., Westgate J. A., Gorton M. P., Jackson S. E., Neal C. R., and Chenery S. P. (1997) A compilation of new and published major and trace element data for NIST SRM 610 and NIST SRM 612 glass reference materials. Geostand. Newsl. 21, 115850 144.

Pingitore N. E., and Eastman M. P. (1984) The experimental partitioning of $\mathrm{Ba}^{2+}$ into calcite. Chem. Geol. 45, 113-120.

Purton L. M. A., Shields G. A., Brasier M. D., and Grime G. W. (1999) Metabolism controls $\mathrm{Sr} / \mathrm{Ca}$ ratios in fossil aragonitic mollusks. Geology 27, 1083-1086.

855 Qiu J. W., Tremblay R., and Bourget E. (2002) Ontogenetic changes in hyposaline tolerance in the mussels Mytilus edulis and M. trossulus: implications for distribution. Mar. Ecol. Prog. Ser. 228, 143-152.

Rosenthal Y., and Katz A. (1989) The applicability of trace elements in freshwater shells for paleogeochemical studies. Chem. Geol. 78, 65-76.

860 Rowley R. J., and Mackinnon D. I. (1995) Use of the flourescent marker calcein in biomineralisation studies of brachiopods and other marine organisms. Bulletin de l'Institut Oceanographique, Monaco 14, 111-120.

Shaw T. J., Moore W. S., Kloepfer J., and Sochaski M. A. (1998) The flux of barium to the coastal waters of the southeastern USA: The importance of submarine groundwater

865 discharge. Geochim. Cosmochim. Acta 62, 3047-3054.

Sinclair D. J. (2005) Non river-flood barium signals in the skeletons of corals from coastal Queensland, Australia. Earth Planet. Sci. Lett. 237, 354-369.

Sinclair D. J., and McCulloch M. T. (2004) Corals record low mobile barium concentrations in the Burdekin River during the 1974 flood: evidence for limited Ba supply to rivers?

870 Palaeogeogr. Palaeoclimat. Palaeoecol. 214, 155-174.

Stecher H. A., and Kogut M. B. (1999) Rapid barium removal in the Delaware estuary. Geochim. Cosmochim. Acta 63, 1003-1012.

Stecher H. A., Krantz D. E., Lord C. J., Luther G. W., and Bock K. W. (1996) Profiles of strontium and barium in Mercenaria mercenaria and Spisula solidissima shells. Geochim.

875 Cosmochim. Acta 60, 3445-3456.

Steenmans D. (2004) Do marine bivalve shells record paleo-productivity? M.Sc. thesis. Vrije Universiteit Brussel, Belgium.

Takesue R. K., and van Geen A. (2004) $\mathrm{Mg} / \mathrm{Ca}, \mathrm{Sr} / \mathrm{Ca}$, and stable isotopes in modern and Holocene Protothaca staminea shells from a northern California coastal upwelling region.

880 Geochim. Cosmochim. Acta 68, 3845-3861.

Tesoriero A. J., and Pankow J. F. (1996) Solid solution partitioning of $\mathrm{Sr}^{2+}, \mathrm{Ba}^{2+}$, and $\mathrm{Cd}^{2+}$ to calcite. Geochim. Cosmochim. Acta 60, 1053-1063. 
Toland H., Perkins B., Pearce N., Keenan F., and Leng M. J. (2000) A study of sclerochronology by laser ablation ICP-MS, J. Ana. Atom. Spectro. 15, 1143-1148.

Torres M. E., Barry J. P., Hubbard D. A, and Suess E. (2001) Reconstructing the history of fluid flow at cold seep sites from $\mathrm{Ba} / \mathrm{Ca}$ ratios in vesicomyid clam shells. Limnol. Oceanogr. 46, 1701-1708.

Tudhope A. W., Lea D. W., Shimmield G. B., Chilcott C. P., and Head S. (1996) Monsoon climate and Arabian Sea coastal upwelling recorded in massive corals from southern

$890 \quad$ Oman. Palaios 11: 347-361.

Vander Putten E., Dehairs F., Keppens E., and Baeyens W. (2000) High resolution distribution of trace elements in the calcite shell layer of modern Mytilus edulis: Environmental and biological controls. Geochim. Cosmochim. Acta 64, 997-1011.

Wada K., and Fujinuki T. (1976) Biomineralization in bivalve molluscs with emphasis on the 895 chemical composition of the extrapallial fluid, In The Mechanisms of Mineralization in the Invertebratesand Plants (eds.N. Watabe and K. M. Wilbur) University of South Carolina Press, Columbia, pp. 175-190.

Weber J. N. (1973) Incorporation of strontium into reef coral skeletal carbonate. Geochim. Cosmochim. Acta 37, 2173-2190.

900 Wheeler A. P. (1992) Mechanisms of molluscan shell formation. In Calcification in Biological Systems (ed. E. Bonucci). CRC press. pp. 179-216.

Wilbur K. M., and Saleuddin A. S. M. (1983) Shell formation. In The Mollusca (eds. A. S. M. Saleuddin and K. M. Wilbur). Academic Press, Inc. pp. 235-287.

Zacherl D. C., Paradis G., and Lea D. W. (2003) Barium and strontium uptake into larval 905 protoconchs and statoliths of the marine neogastropod Kelletia kelledi. Geochim. Cosmochim. Acta 67, 4091-4099.

Zwolsman J. J. G., and van Eck G. T. M. (1999) Geochemistry of major elements and trace metals in suspended matter of the Scheldt estuary, southwest Netherlands. Mar. Chem. 66, 91-111. 
Table 1. Summary of average seawater $[\mathrm{Ba} / \mathrm{Ca}]_{\text {water }}( \pm \mathrm{SE})$ for each laboratory $[\mathrm{Ba} / \mathrm{Ca}]_{\text {water }}$ treatment group. $\mathrm{N}=8$ water samples per treatment, spread over the 915 experiment.

\begin{tabular}{llc}
\hline Tank & Treatment $*$ & {$[\mathrm{Ba} / \mathrm{Ca}]_{\text {water }}(\mu \mathrm{mol} / \mathrm{mol})$} \\
\hline 1 & Ambient & $5.08 \pm 0.22$ \\
2 & $+110 \mathrm{nmol} \mathrm{l}^{-1}$ & $19.38 \pm 0.71$ \\
3 & $+220 \mathrm{nmol} \mathrm{l}^{-1}$ & $36.34 \pm 0.91$ \\
4 & $+440 \mathrm{nmol} \mathrm{l}^{-1}$ & $65.05 \pm 2.37$ \\
5 & Feeding* $^{*}$ & $4.61 \pm 0.45$ \\
\hline * & &
\end{tabular}




\section{Figure legends}

920 Figure 1. Map of the Westerschelde and Oosterschelde estuaries. The mussel collection site at Wemeldinge (WD) and the four study sites are indicated: Knokke (KN), Hooftplaat (HF), Griete (GR) and Ossenisse (OS). Scale bar $=10 \mathrm{~km}$.

925 Figure 2. Mean $\mathrm{Ba} / \mathrm{Ca}$ ratios $( \pm \mathrm{SE}$ ) in hemolymph of laboratory grown Mytilus edulis versus $\mathrm{Ba} / \mathrm{Ca}$ ratios of culturing water ( $\pm \mathrm{SE}$; solid circles). Some error bars are smaller than the symbols. The solid line shows the linear least squares regression, with the relationship $[\mathrm{Ba} / \mathrm{Ca}]_{\text {hemolymph }}=0.86( \pm 0.04) *$ $[\mathrm{Ba} / \mathrm{Ca}]_{\text {water }}+2.26( \pm 1.49)\left(\mathrm{R}^{2}=0.98, \mathrm{p}<0.0001, \mathrm{n}=36\right.$ in 4 treatments $)$. The 1:1 line is also shown (dashed). Data from the feeding experiment, where the mussels were fed food enriched in $\mathrm{Ba}$ are shown as the $\mathrm{X}$ and diamond. The inset graph illustrates that food [Ba] does not influence hemolymph $\mathrm{Ba} / \mathrm{Ca}$ ratios ( $\mathrm{y}$-axis legend is the same as the main graph).

Figure 3. Mean $\mathrm{Ba} / \mathrm{Ca}$ ratios $( \pm \mathrm{SE})$ in bulk tissue of laboratory grown Mytilus edulis versus $\mathrm{Ba} / \mathrm{Ca}$ ratios of culturing water ( $\pm \mathrm{SE}$; solid circles). Some error bars are smaller than the symbols. The solid line shows the exponential fit, with the relationship $[\mathrm{Ba} / \mathrm{Ca}]_{\text {tissue }}=35.36( \pm 2.19) *\left(1-\exp ^{(-0.07}( \pm 0.01) *\right.$ $\left.{ }^{[\mathrm{Ba} / \mathrm{Ca}] \text { water })}\right)\left(\mathrm{R}^{2}=0.99, \mathrm{p}<0.0001, \mathrm{n}=11\right.$ in 4 treatments $)$. Data from the feeding experiment, where the mussels were fed food enriched in $\mathrm{Ba}$ are shown as the open symbols. The inset graph illustrates that food [Ba] clearly does influence tissue $\mathrm{Ba} / \mathrm{Ca}$ ratios (y-axis legend is the same as the main graph).

945 Figure 4. Mean $\mathrm{Ba} / \mathrm{Ca}$ ratios $( \pm \mathrm{SE}$ ) in shells of laboratory grown Mytilus edulis versus $\mathrm{Ba} / \mathrm{Ca}$ ratios of culturing water $( \pm \mathrm{SE})$. Some error bars are smaller than the symbols. The solid line shows the linear least squares regression, with the relationship $[\mathrm{Ba} / \mathrm{Ca}]_{\text {shell }}=0.10( \pm 0.02) *[\mathrm{Ba} / \mathrm{Ca}]_{\text {water }}+1.00( \pm$ 0.68) $\left(\mathrm{R}^{2}=0.84, \mathrm{p}<0.0001, \mathrm{n}=28\right.$ in 4 treatments $)$. The dashed line represents the regression forced through zero. 
Figure 5. Dissolved $[\mathrm{Ba} / \mathrm{Ca}]_{\text {water }}(\mathrm{A})$, salinity (B) and $\mathrm{Chl}$ a (C) at the four Schelde sites measured over one year (Nov. 2001 - Nov. 2002). See Fig. 1 for site abbreviations.

955

Figure 6. Salinity versus $[\mathrm{Ba} / \mathrm{Ca}]_{\text {water, }}$ including data from all sites and sampling dates, with the linear relationship $[\mathrm{Ba} / \mathrm{Ca}]_{\text {water }}=-1.22( \pm 0.21) *$ Salinity + $46.05( \pm 4.57)\left(R^{2}=0.73, n=55, p<0.0001\right)$. See Fig. 1 for site abbreviations.

960

Figure 7. High resolution $\delta^{18} \mathrm{O}, \delta^{13} \mathrm{C}$, and $[\mathrm{Ba} / \mathrm{Ca}]_{\text {shell }}$ profiles from the six shells. Black filled symbols denote data selected as background $[\mathrm{Ba} / \mathrm{Ca}]_{\text {shell }}$ data. Vertical lines correspond to the time of transplantation (HF and GR shells only, see Materials and methods) as determined from the calcein stain. Shell codes represent collection site and date (format: ddmmyy). Note that the isotope axes are inverted.

Figure 8. Mean $[\mathrm{Ba} / \mathrm{Ca}]_{\text {shell }}( \pm \mathrm{SE})$ in shells of laboratory grown (closed symbols; based on 28 shells from 4 treatments) and field grown (open symbols; based on multiple data from 6 shells from 4 sites, background data only) Mytilus edulis versus $\mathrm{Ba} / \mathrm{Ca}$ ratios of water $( \pm \mathrm{SE})$. The average $[\mathrm{Ba} / \mathrm{Ca}]_{\text {water }}$ over the whole year is used for the field regression (see text, section 4.2). The solid line shows the linear least squares regressions and the dashed lines the $95 \%$ CI. Slopes are significantly different (t-test) at $\mathrm{p}<0.0001$. 


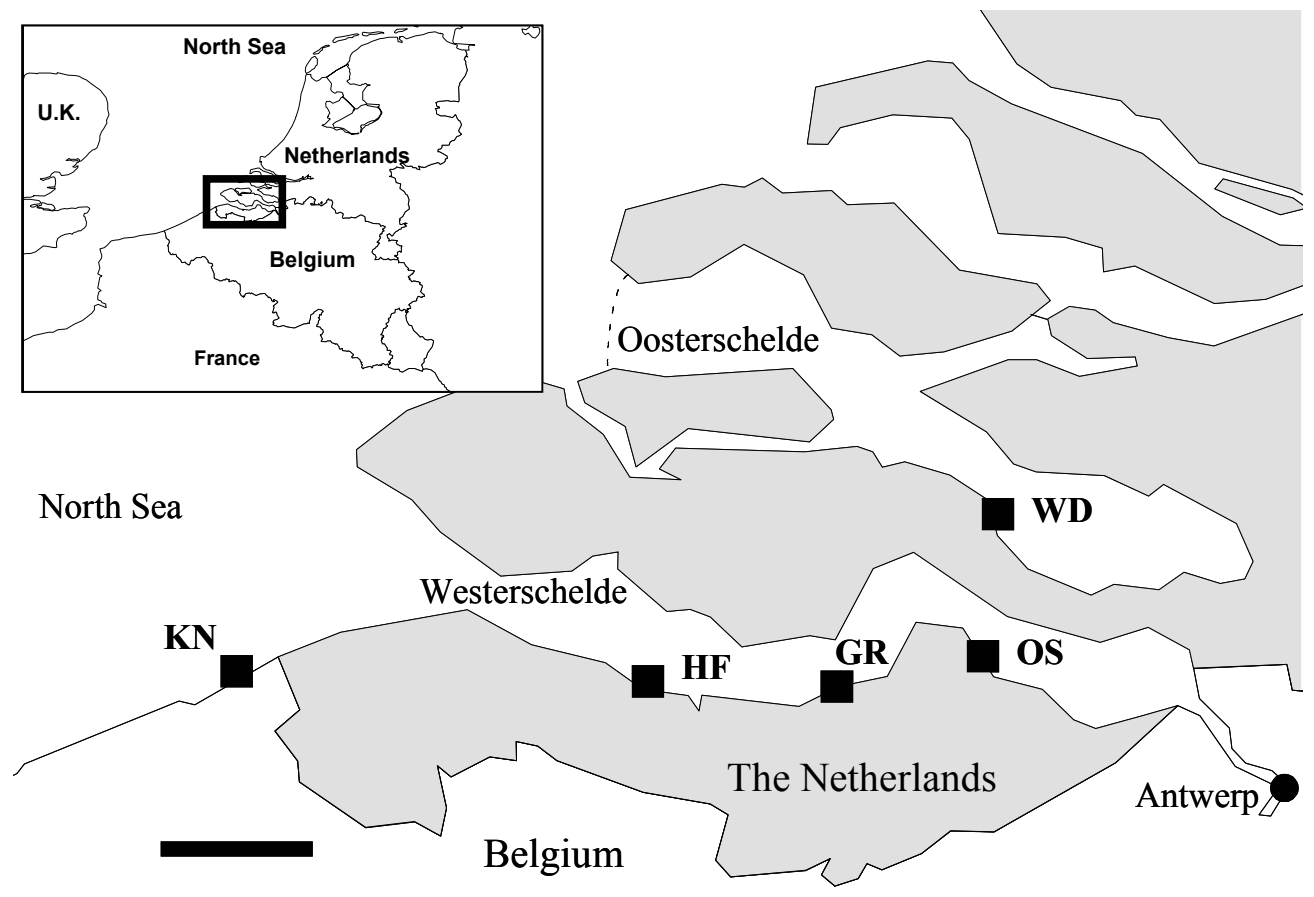

Figure 1. Map of the Westerschelde and Oosterschelde estuaries. The mussel collection site at Wemeldinge (WD) and the four study sites are indicated: Knokke (KN), Hooftplaat (HF), Griete (GR) and Ossenisse (OS). Scale bar $=10 \mathrm{~km}$. 


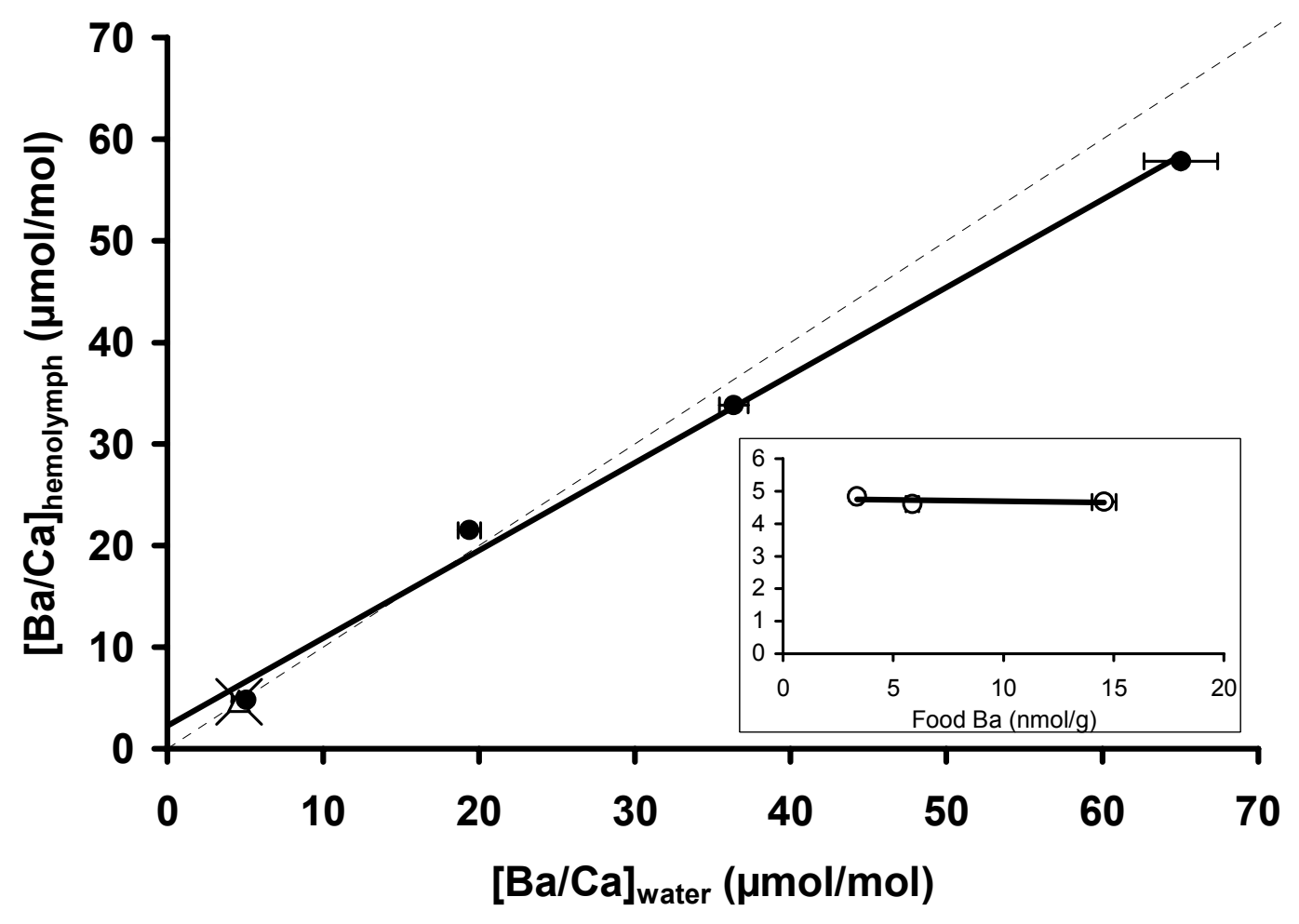

Figure 2. Mean $\mathrm{Ba} / \mathrm{Ca}$ ratios $( \pm \mathrm{SE}$ ) in hemolymph of laboratory grown Mytilus edulis versus $\mathrm{Ba} / \mathrm{Ca}$ ratios of culturing water ( $\pm \mathrm{SE}$; solid circles). Some error bars are smaller than the symbols. The solid line shows the linear least squares regression, with the relationship $[\mathrm{Ba} / \mathrm{Ca}]_{\text {hemolymph }}=0.86( \pm 0.04) *[\mathrm{Ba} / \mathrm{Ca}]_{\text {water }}+2.26( \pm 1.49)\left(\mathrm{R}^{2}=0.98, \mathrm{p}\right.$ $<0.0001, \mathrm{n}=36$ in 4 treatments). The 1:1 line is also shown (dashed). Data from the feeding experiment, where the mussels were fed food enriched in $\mathrm{Ba}$ are shown as the $\mathrm{X}$ and diamond. The inset graph illustrates that food $[\mathrm{Ba}]$ does not influence hemolymph $\mathrm{Ba} / \mathrm{Ca}$ ratios ( $\mathrm{y}$-axis legend is the same as the main graph). 


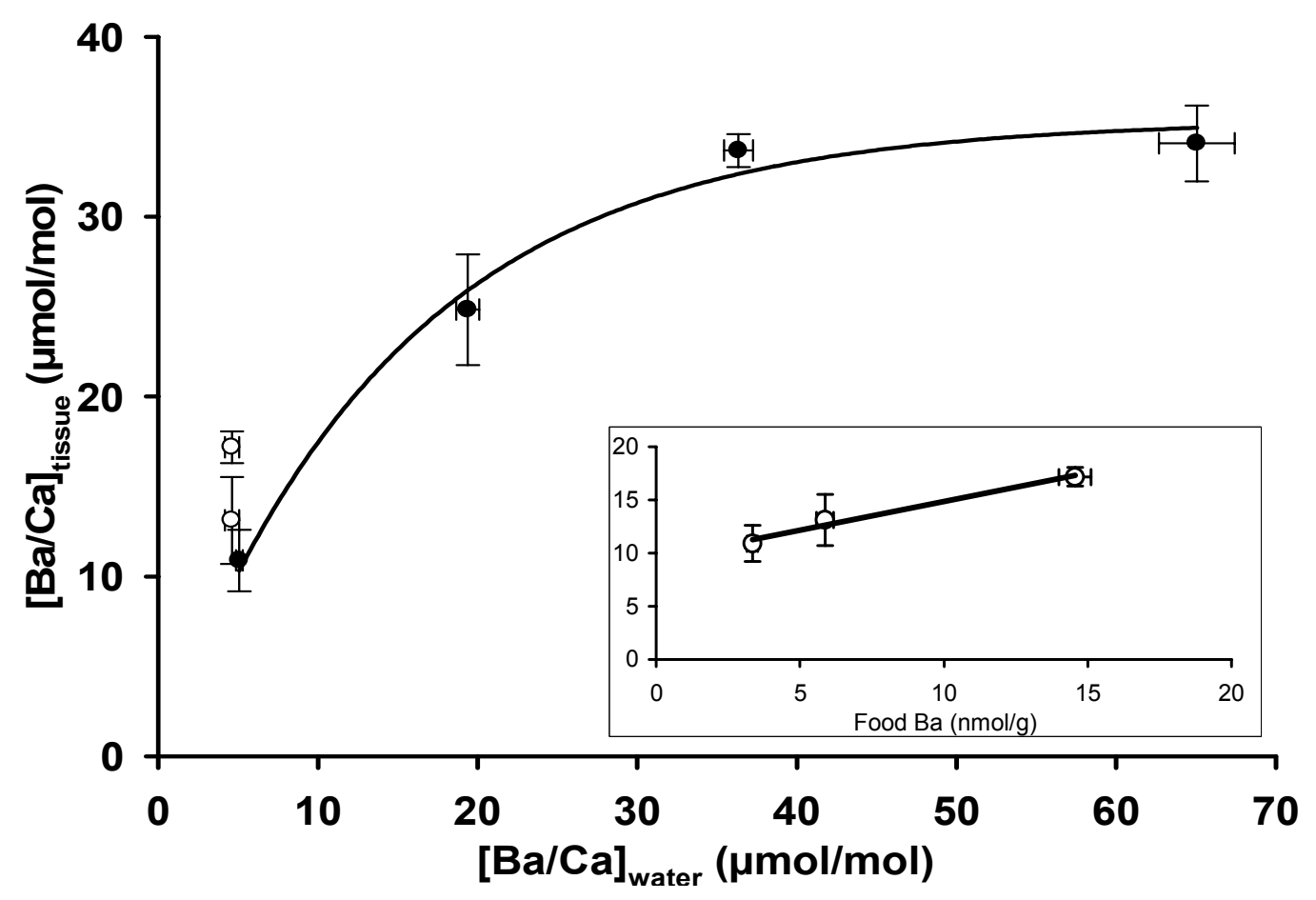

Figure 3. Mean $\mathrm{Ba} / \mathrm{Ca}$ ratios $( \pm \mathrm{SE}$ ) in bulk tissue of laboratory grown Mytilus edulis versus $\mathrm{Ba} / \mathrm{Ca}$ ratios of culturing water ( $\pm \mathrm{SE}$; solid circles). Some error bars are smaller than the symbols. The solid line shows the exponential fit, with the relationship $[\mathrm{Ba} / \mathrm{Ca}]_{\text {tissue }}=35.36( \pm 2.19) *\left(1-\exp ^{(-0.07( \pm 0.01) *[\mathrm{Ba} / \mathrm{Ca}] \text { water })}\right)\left(\mathrm{R}^{2}=0.99, \mathrm{p}<0.0001, \mathrm{n}=\right.$ 11 in 4 treatments). Data from the feeding experiment, where the mussels were fed food enriched in $\mathrm{Ba}$ are shown as the open symbols. The inset graph illustrates that food [Ba] clearly does influence tissue $\mathrm{Ba} / \mathrm{Ca}$ ratios ( $\mathrm{y}$-axis legend is the same as the main graph). 


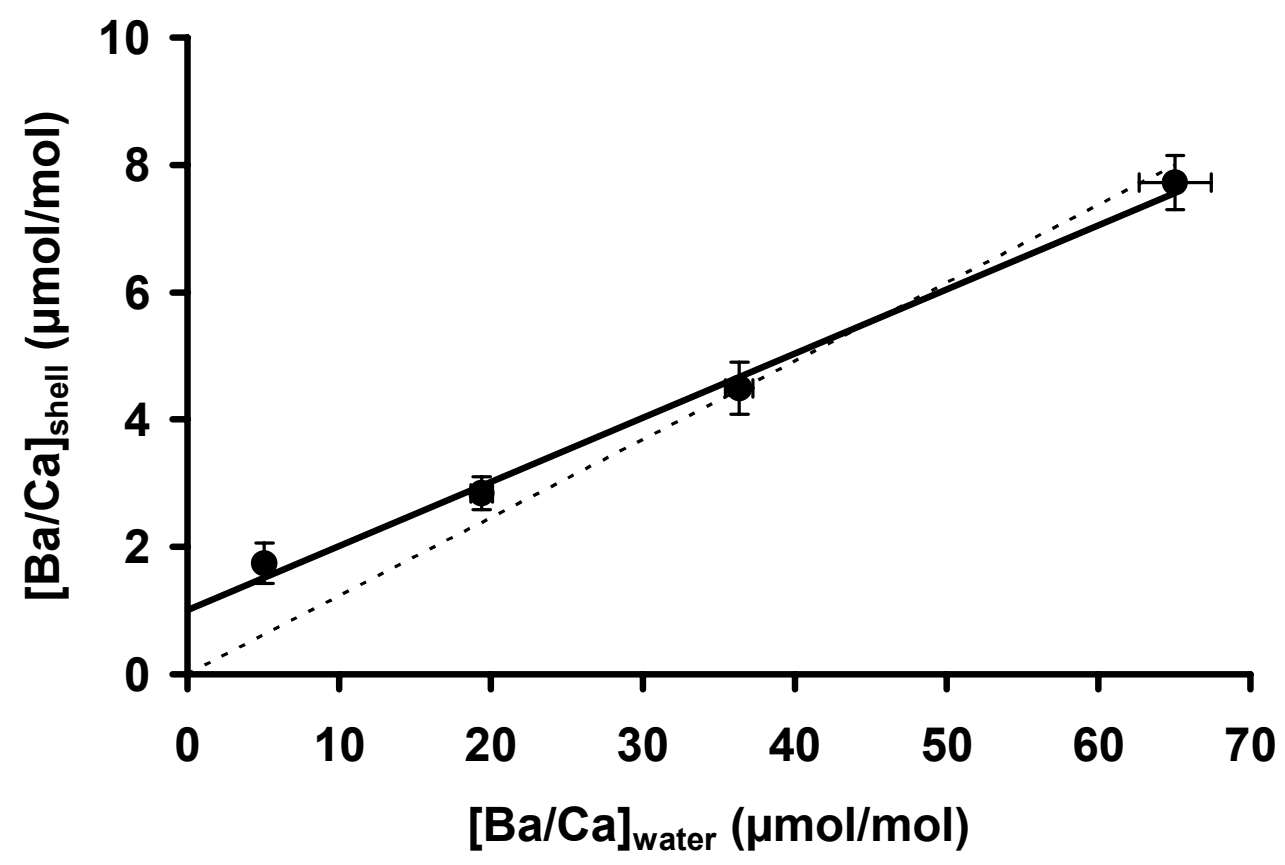

Figure 4. Mean $\mathrm{Ba} / \mathrm{Ca}$ ratios $( \pm \mathrm{SE})$ in shells of laboratory grown Mytilus edulis versus $\mathrm{Ba} / \mathrm{Ca}$ ratios of culturing water $( \pm \mathrm{SE})$. Some error bars are smaller than the symbols. The solid line shows the linear least squares regression, with the relationship $[\mathrm{Ba} / \mathrm{Ca}]_{\text {shell }}=$ $0.10( \pm 0.02) *[\mathrm{Ba} / \mathrm{Ca}]_{\text {water }}+1.00( \pm 0.68)\left(\mathrm{R}^{2}=0.84, \mathrm{p}<0.0001, \mathrm{n}=28\right.$ in 4 treatments). The dashed line represents the regression forced through zero. 

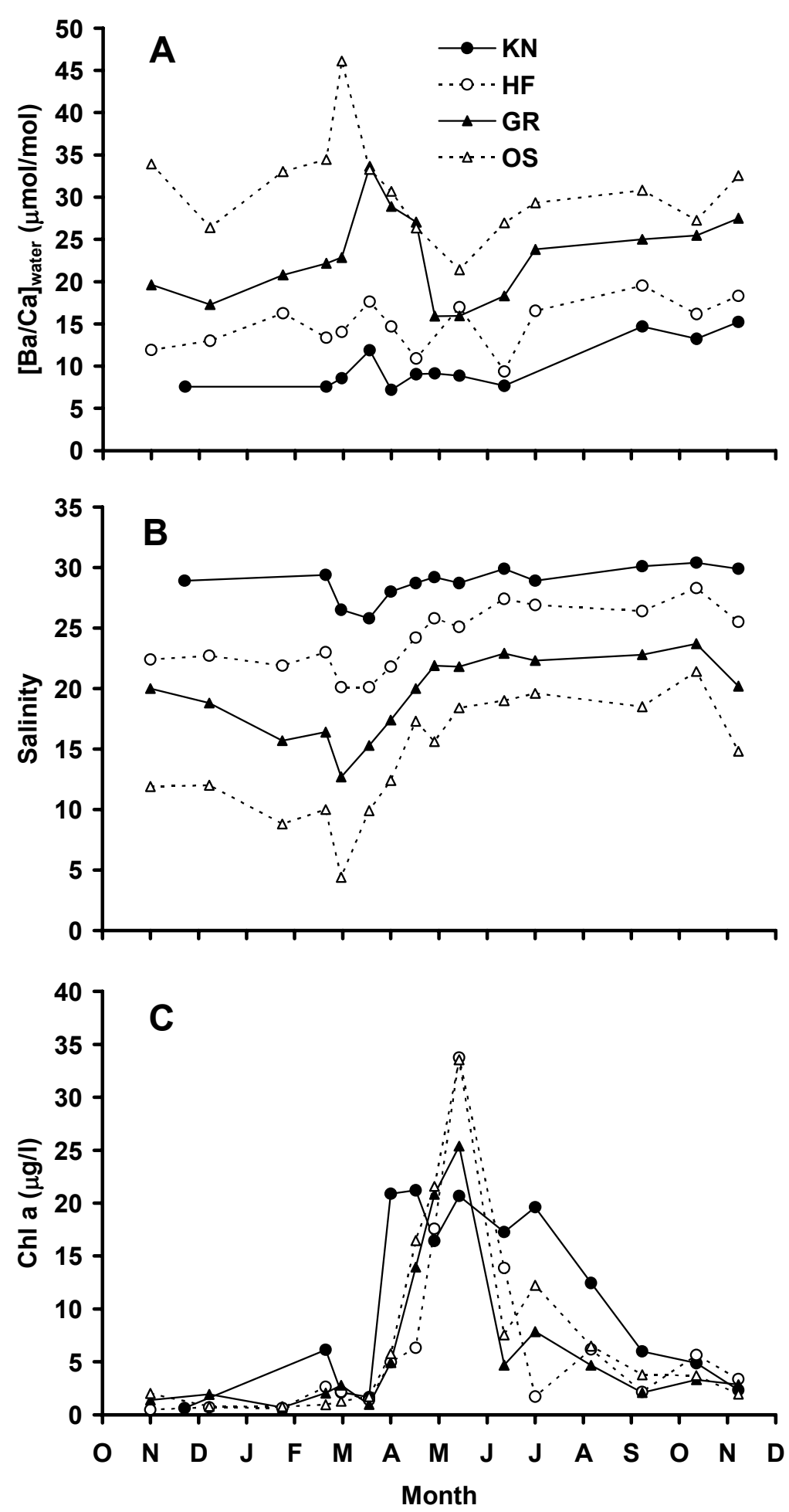

Figure 5. Dissolved $[\mathrm{Ba} / \mathrm{Ca}]_{\text {water }}(\mathrm{A})$, salinity (B) and $\mathrm{Chl}$ a $(\mathrm{C})$ at the four Schelde sites measured over one year (Nov. 2001 - Nov. 2002). See Fig. 1 for site abbreviations. 


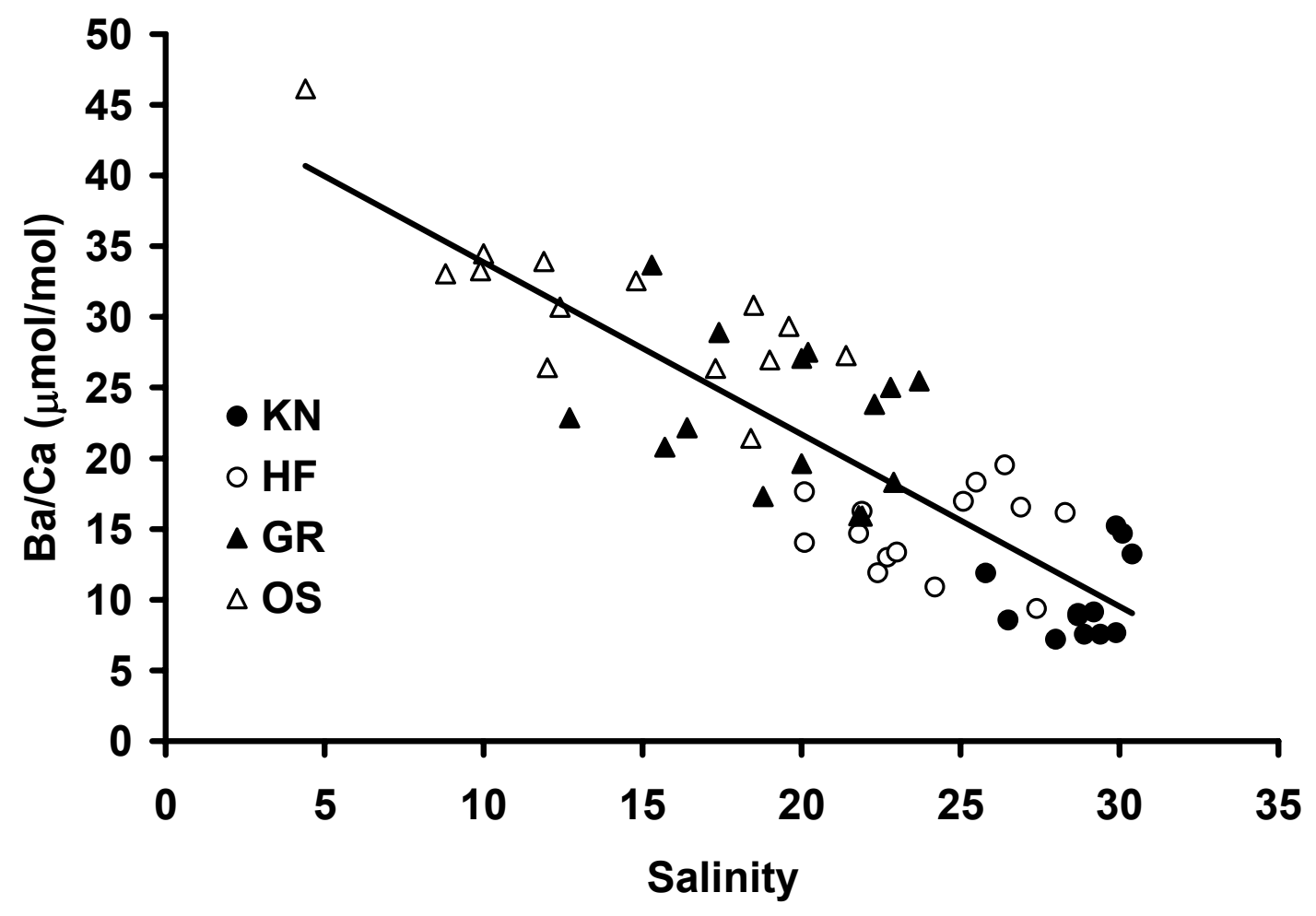

Figure 6. Salinity versus $[\mathrm{Ba} / \mathrm{Ca}]_{\text {water }}$, including data from all sites and sampling dates, with the linear relationship $[\mathrm{Ba} / \mathrm{Ca}]_{\text {water }}=-1.22( \pm 0.21) *$ Salinity $+46.05( \pm 4.57)\left(\mathrm{R}^{2}=\right.$ $0.73, \mathrm{n}=55, \mathrm{p}<0.0001)$. See Fig. 1 for site abbreviations. 

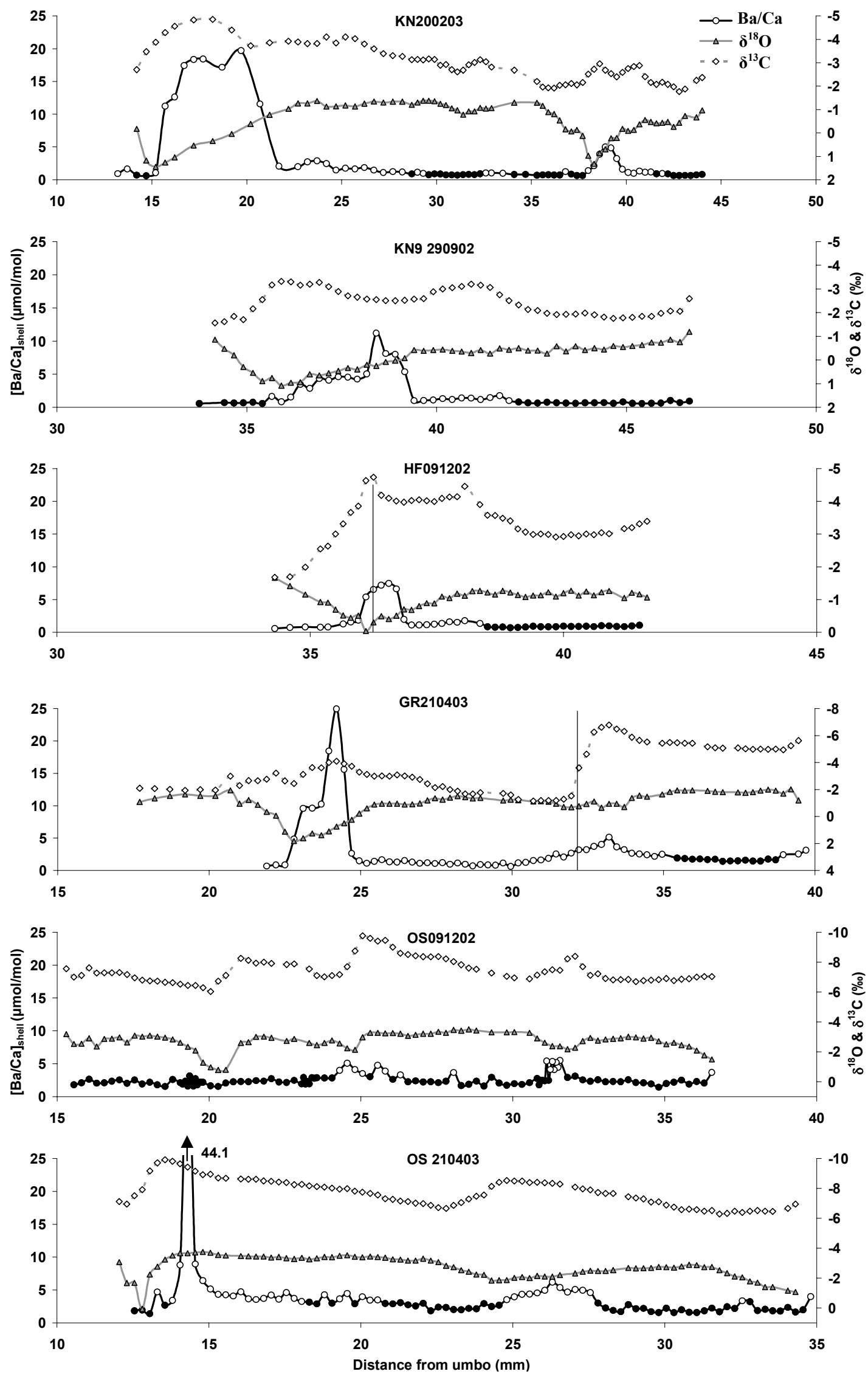

Figure 7. High resolution $\delta^{18} \mathrm{O}, \delta^{13} \mathrm{C}$, and $[\mathrm{Ba} / \mathrm{Ca}]_{\text {shell }}$ profiles from the six shells. Black filled symbols denote data selected as background $[\mathrm{Ba} / \mathrm{Ca}]_{\text {shell }}$ data. Vertical lines correspond to the time of transplantation (HF and GR shells only, see Materials and methods) as determined from the calcein stain. Shell codes represent collection site and date (format: ddmmyy). Note that the isotope axes are inverted. 


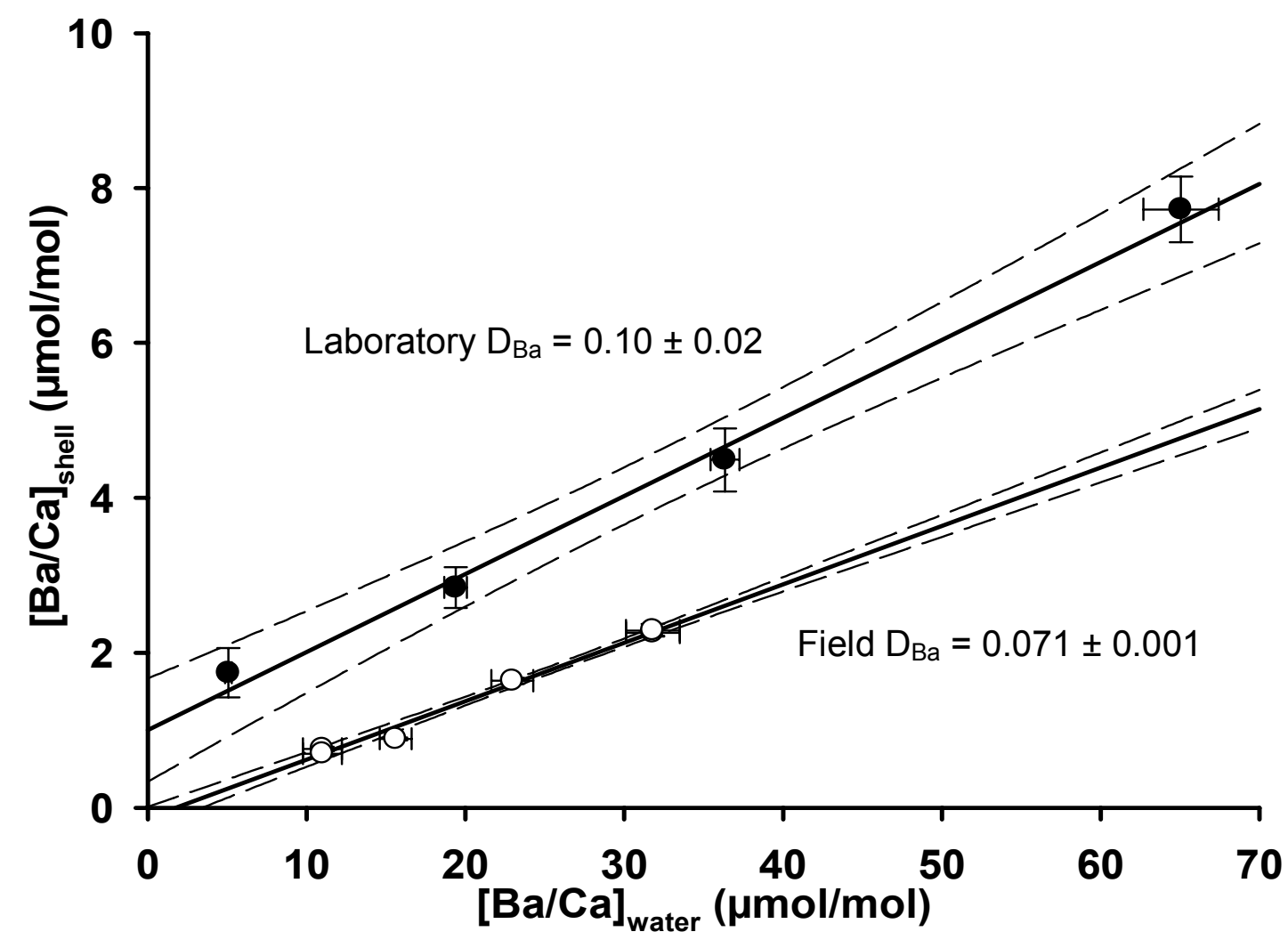

Figure 8. Mean $[\mathrm{Ba} / \mathrm{Ca}]_{\text {shell }}( \pm \mathrm{SE})$ in shells of laboratory grown (closed symbols; based on 28 shells from 4 treatments) and field grown (open symbols; based on multiple data from 6 shells from 4 sites, background data only) Mytilus edulis versus mean $[\mathrm{Ba} / \mathrm{Ca}]_{\text {water }}$ $( \pm \mathrm{SE})$. The average $[\mathrm{Ba} / \mathrm{Ca}]_{\text {water }}$ over the whole year is used for the field regression (see text, section 4.2). The solid line shows the linear least squares regressions and the dashed lines the $95 \%$ CI. Slopes are significantly different (t-test) at $\mathrm{p}<0.0001$. 


\section{Electronic Annex Captions}

EA1: Summary of Ba/Ca data

EA2: Summary of field data 